\title{
CREDIBILITY OF CORPORATE
}

ANNOUNCEMENTS

AND MARKET REACTION:

EVIDENCE FROM CANADIAN

SHARE REPURCHASE PROGRAMS

\author{
A Thesis Submitted to the College of \\ Graduate Studies and Research \\ In Partial Fulfillment of the Requirements \\ For the Degree of Master of Science \\ In the Department of Finance and Management Science \\ University of Saskatchewan \\ Saskatoon, Saskatchewan, Canada
}

By

Luke Schmidt

(c) Copyright Luke Schmidt, November, 2006. All rights reserved. 


\section{PERMISSION TO USE}

In presenting this thesis in partial fulfilment of the requirements for a Postgraduate degree from the University of Saskatchewan, I agree that the Libraries of this University may make it freely available for inspection. I further agree that permission for copying of this thesis in any manner, in whole or in part, for scholarly purposes may be granted by the professor or professors who supervised my thesis work or, in their absence, by the Head of the Department or the Dean of the College in which my thesis work was done. It is understood that any copying or publication or use of this thesis or parts thereof for financial gain shall not be allowed without my written permission. It is also understood that due recognition shall be given to me and to the University of Saskatchewan in any scholarly use which may be made of any material in my thesis.

Requests for permission to copy or to make other use of material in this thesis in whole or part should be addressed to:

Head of the Department of Finance and Management Science

College of Commerce

University of Saskatchewan

25 Campus Drive

Saskatoon, Saskatchewan

S7N 5A7 


\begin{abstract}
Firms that announce open-market share repurchase programs are not obligated to follow through in the actual acquisition of shares. In fact, we find that the majority of firms fail to acquire the target number of shares specified at announcement and many firms fail to repurchase any shares at all. Therefore, the announcement of a share repurchase program has a degree of uncertainty regarding the announcing firm's credibility. This study examines the possibility that market participants evaluate the credibility of a firm's share repurchase announcement based on the firm’s previous share repurchase history. We examine 1,507 share repurchase programs for firms listed on the Toronto Stock Exchange (TSX) from 1995 to 2005 and find that firms that have completed a higher proportion of previous share repurchase programs experience larger abnormal returns on the announcement of subsequent repurchase programs. Therefore, we conclude that the market reacts more favorably to the share repurchase announcements of credible firms compared to firms that lack credibility.
\end{abstract}




\section{ACKNOWLEDGMENTS}

I would like to express my sincere gratitude to my thesis co-supervisors, Dev Mishra and Marie Racine, for their guidance, insight, and encouragement. Their support was imperative to the creation of this thesis. They generously sacrificed a significant amount of their time and effort and I thank them for their patience and perseverance. I would also like to thank my internal examiner, George Tannous, and my external examiner, Gary Entwistle, for their comments and suggestions. Lastly, I would like to acknowledge all of the faculty and staff of the Department of Finance and Management Science for their assistance during my studies at the University. 


\section{TABLE OF CONTENTS}

page

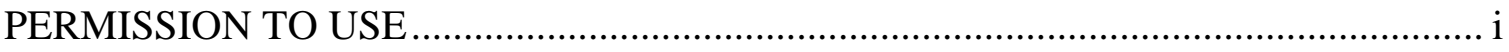

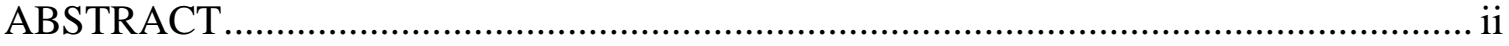

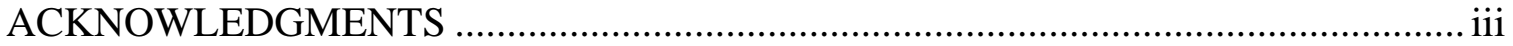

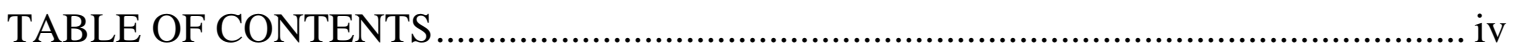

LIST OF FIGURES ................................................................................... vi

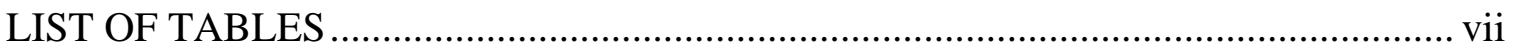

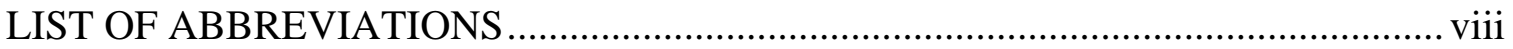

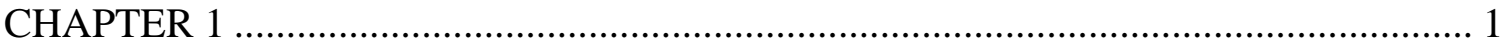

INTRODUCTION

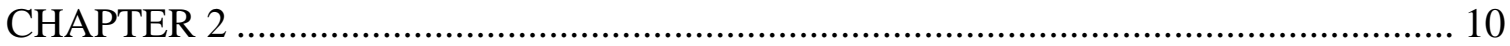

OVERVIEW OF CANADIAN SHARE REPURCHASE MARKET REGULATION

CHAPTER 3

3.1 Why Do Companies Repurchase Stock? ..................................................... 17

3.1.1 Signaling and/or undervaluation hypothesis 17

3.1.2 Excess cash distribution and dividend substitution hypothesis $\quad 20$

3.1.3 Increasing earnings per share and/or offset dilution of employee $\begin{array}{ll}\text { stock options } & 23\end{array}$

3.1.4 Capital structure adjustment 25

$\begin{array}{ll}\text { 3.1.5 Tax benefit of repurchases versus dividends } & 26\end{array}$

3.2 Actual Acquisition of Shares in Repurchase Programs....................................... 27

$\begin{array}{ll}3.2 .1 \text { Estimation of share repurchase completion rates } & 27\end{array}$

3.2.2 Factors that determine share repurchase completion rates 30

3.2.3 Effect of share repurchases on liquidity and prices 30

CHAPTER 4

SAMPLE CONSTRUCTION AND METHODOLOGY

4.1 Share Repurchase Activity and Completion Rates........................................... 37

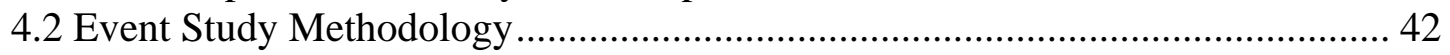

4.3 Short-term Repurchase Announcement Abnormal Returns................................ 44 
CHAPTER 5

ANNOUNCEMENT CREDIBILITY AND REPUTATIONAL EFFECTS

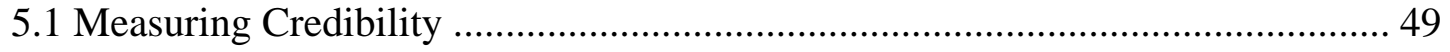

$\begin{array}{ll}\text { 5.1.1 Credibility index A } & 50\end{array}$

$\begin{array}{ll}\text { 5.1.2 Adjusted credibility index B } & 51\end{array}$

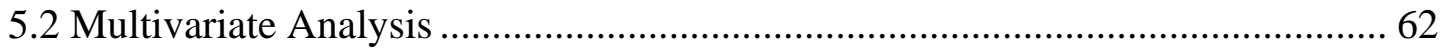

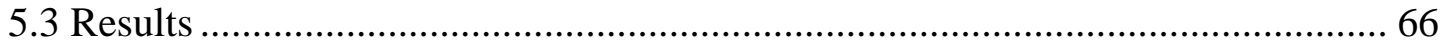

5.3.1 Multivariate results for credibility index A 66

$\begin{array}{ll}\text { 5.3.2 Multivariate results for credibility index B } & 74\end{array}$

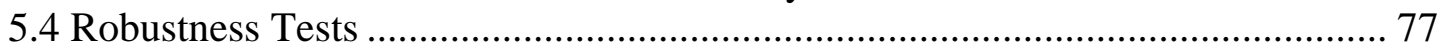

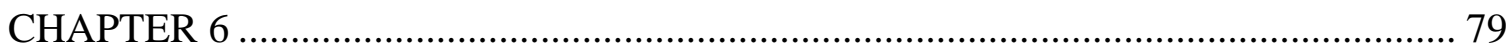

CONCLUSION

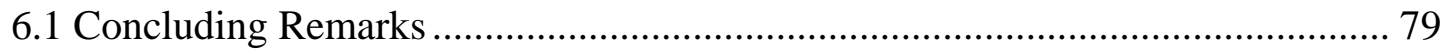

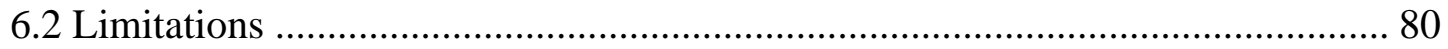

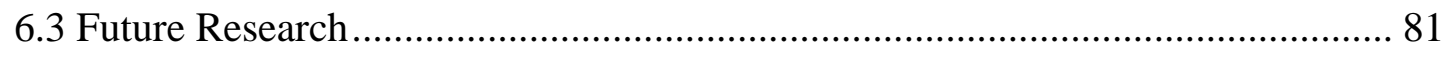

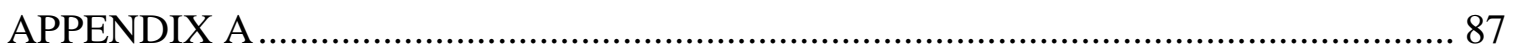

CORRELATION MATRICES FOR TABLE 5-2

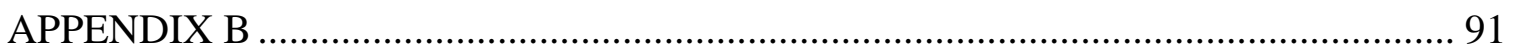

REUSLTS FROM ALTERNATIVE EVENT STUDY METHODOLOGIES

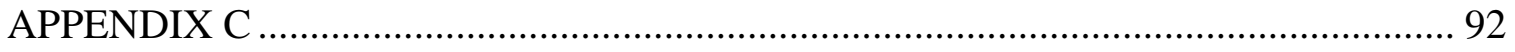

CONSTRUCTION OF ALTERNATIVE CREDIBILITY INDICES

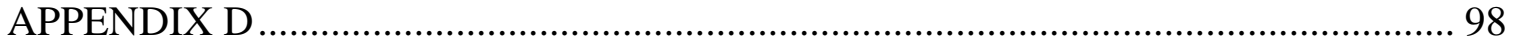

TSX E-REVIEW SHARE REPURCHASE SUMMARY 


\section{LIST OF FIGURES}

$\underline{\text { Figure }}$

page

Figure 1-1. Aggregate cash distributions to shareholders in Canada............................... 3

Figure 1-2. Firm-specific examples of share repurchase histories ............................... 7

Figure 4-1. Frequency of share repurchase announcements ....................................... 36

Figure 4-2. Share repurchase activity in Canada between 1995 and 2005 .................... 39

Figure 4-3. Histogram of distribution of share repurchase completion rates ................. 41

Figure D-1. Example of TSX share repurchase summary ......................................... 99

Figure D.2. Copy of the written correspondence from the TSX authorizing the inclusion of the material in Figure D-1 100 


\section{LIST OF TABLES}

$\underline{\text { Table }}$

page

Table 3-1. Summary of empirical findings of share repurchase announcement abnormal returns ...................................................................................... 16

Table 4-1. Share repurchase announcements, completion rates, and average size of announcing firms.

Table 5-1A. Abnormal returns for each quartile of credibility index A ......................... 61

Table 5-1B. Abnormal returns for each quartile of credibility index B......................... 61

Table 5-2. Descriptive statistics for sample used in multivariate regression.................. 65

Table 5-3. Multivariate regression results for credibility index A................................. 68

Table 5-5. Multivariate regression results for credibility index B............................... 76

Table A-1. Correlation matrix for Table 5-3, Models 1 and 2.................................... 87

Table A-2. Correlation matrix for Table 5-3, Model 3 .............................................. 88

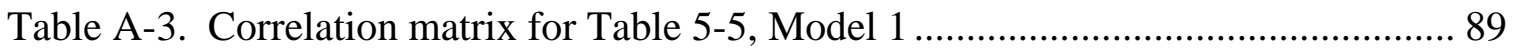

Table A-4. Correlation matrix for Table 5-5, Model 2 .............................................. 90

Table B-1. Robustness tests using alternative event study methodologies..................... 91

Table C-1. Multivariate regression results for previous completion dummy and previous completion >median dummy ................................................ 96

Table C-2. Multivariate regression results for credibility index B2, B3, and B4 ........... 97 


\section{LIST OF ABBREVIATIONS}

Abbreviation

first page of appearance

Canadian Financial Markets Research Center (CFMRC) 3

Center for Research in Security Prices (CRSP) 27

cumulative abnormal return (CAR) $\quad 43$

$\begin{array}{ll}\text { earnings per share (EPS) } & 17\end{array}$

Electronic Data Gathering, Analysis, and Retrieval system (EDGAR) 33

$\begin{array}{ll}\text { net present value (NPV) } & 20\end{array}$

New York Stock Exchange (NYSE) 31

Securities and Exchange Commission (SEC) 10

Standard and Poor's (S\&P) 1

System for Electronic Document Analysis and Retrieval (SEDAR) 33

Toronto Stock Exchange (TSX) 


\section{CHAPTER 1 \\ INTRODUCTION}

Historically, dividends have been the primary method of returning wealth to shareholders. Over the last 20 years, a drastic change in the payout policy regime has occurred and share repurchases have emerged as the dominant method of distributing corporate cash flows in North America. In 1980, U.S. corporations repurchased approximately $\$ 6.6$ billion of shares accounting for 4.8 percent of total earnings (Grullon and Michaely, 2002). In 1999, share repurchases increased to \$202.8 billion and accounted for 41.8 percent of earnings, compared to $\$ 197.8$ billion paid out as dividends that year. This marked the first time in history that share repurchases overtook dividends as the preferred choice of corporate payout. Recent data verifies that the trend of increasing share repurchases continues; in 2005, constituent companies of the S\&P 500 repurchased $\$ 349$ billion of shares, compared to $\$ 202$ billion paid out as dividends. ${ }^{1}$

In Canada, the statistics on payout policy are very similar to those of the U.S. Figure 1-1 illustrates the aggregate cash payouts of Canadian firms listed on the Toronto Stock Exchange (TSX). In 2000, open-market share repurchases surpassed dividends as the primary means of distributing cash-flow to investors. Another noteworthy observation is that share repurchases seem to be cyclical and are much more volatile than

\footnotetext{
${ }^{1}$ According to data released by Standard and Poor's (S\&P) in a press release dated June 12, 2006.
} 
dividend payments. In 2001, share repurchases declined relative to dividends, only to surpass dividend payments again in 2004. This suggests that the increase in open-market share repurchases is not a temporary trend. 


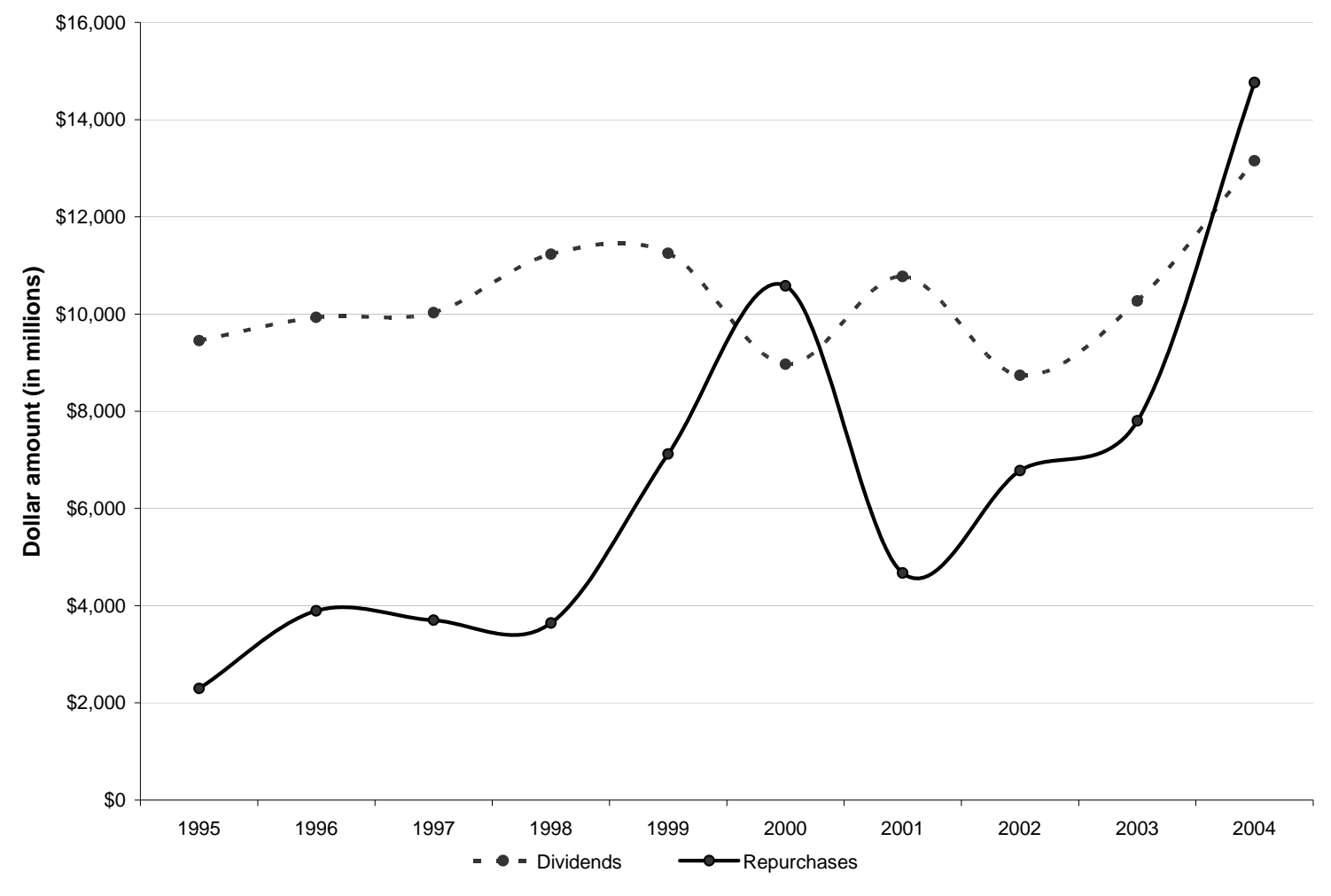

Figure 1-1. Aggregate cash distributions to shareholders in Canada

This figure plots annual aggregate cash distributions for Canadian corporations listed on the Toronto Stock Exchange (TSX). For dividends, the sample includes all cash dividend observations (regular and special) on the CFMRC database (Canadian Financial Markets Research Centre). For repurchases, the sample includes all open-market share repurchases reported to the TSX. The estimate of the dollar amount of repurchases is calculated using the closing share price at the end of the month prior to the announcement of the repurchase program multiplied by the number of shares actually repurchased in the 12 months subsequent to the repurchase announcement. 
Extant literature overwhelmingly finds a positive price reaction for firms around the announcement of a share repurchase program. ${ }^{2}$ However, firms that announce openmarket share repurchase programs are not obligated to follow through in the actual acquisition of shares. In reality, the majority of firms fail to acquire the number of shares specified in the share repurchase announcement and many firms fail to repurchase any shares at all.

Figure 1-2 provides the share repurchase history for three companies listed on the TSX. The figure illustrates the differences in the completion consistency of share repurchase programs among firms. ${ }^{3}$ Out of the ten share repurchase announcements made between 1995 to 2005, Cogeco Cable Inc. partially fulfilled five announcements (3\% to $62 \%$ completion rate) and did not fulfill four announcements at all. One announcement is still pending. Similarly, the Bank of Montreal, one of the largest Canadian banks, made six share repurchase announcements during this period. It fulfilled one announcement completely and four announcements partially (34\% to $92 \%$ completion rate). It did not follow through on one announcement. While Dundee Realty

${ }^{2}$ See Table 3-1 for a summary of the extant literature on share repurchase announcement abnormal returns.

Besides open-market share repurchases, firms can use tender offers or Dutch auctions as a method to repurchase shares. However, open-market share repurchases are by far the most popular method to repurchase shares. This paper only analyzes open-market share repurchases. Therefore, for the remainder of this paper share repurchase, stock buyback, and repurchase program all refer to open-market share repurchases.

${ }^{3}$ In Canada, due to TSX regulations, share repurchase programs are valid for a period of 12 months. Therefore, each column of data in Figure 1-2 represents a separate share repurchase program. 
Corporation made four announcements and fulfilled all of them almost completely. The company in example 1 can be described as a firm with a reputation for fully completing its announced share repurchase programs. On the other hand, the company in example 2 can be described as a firm with a reputation for not completing (or even attempting to complete) its announced share repurchase programs. Therefore, it is likely that the market would regard any future share repurchase announcement by the company in example 1 as "credible". However, any future repurchase announcement for the firm in example 2 will likely be perceived as less "credible". Accordingly, the market may use the reputation of a repurchasing firm to evaluate the credibility of the repurchase announcement when analyzing the informational content of the share repurchase announcement.

Until recently, studies on share repurchases have overlooked the fact that, unlike other corporate events, share repurchase announcements are not firm commitments. That is, there is a degree of uncertainty to the likelihood that a firm will actually followthrough on its announced intentions. The firms that fail to substantially meet their past share repurchase commitments, obviously, are less likely to attract market attention with their future announcements. In other words, the credibility and reputation established through the fulfillment of past commitments may play a crucial role in the evaluation of the informational content of a share repurchase announcement. For example, Oded (2005) speculates "reputation effects can provide an alternative explanation for the announcement return without a commitment to repurchase.” However, Oded does not examine this issue empirically. Similarly, Chan et al. (2004) and Stephens and Weisbach (1998) suggest the possible role of credibility and reputational effects in the explanation of the cross-sectional variation of abnormal price reactions around share repurchase 
announcements. However, this issue has not been extensively examined to date. We attempt to resolve the void in the current literature by investigating how credibility and reputation implicit in the past behavior of announcing firms affect the market reaction to their subsequent share repurchase announcements. 
Example 1 - Dundee Realty Corporation

\begin{tabular}{|c|c|c|c|c|c|c|c|c|c|c|}
\hline Year & $1995 \quad 1996$ & 1997 & 1998 & 1999 & 2000 & 2001 & 2002 & 2003 & 2004 & 2005 \\
\hline \# of shares announced to be repurchased (in millions) & & & 14.3 & 11.9 & 1.3 & 1.0 & & & & \\
\hline \# of shares actually repurchased (in millions) & & & 14.3 & 11.8 & 1.3 & 1.0 & & & & \\
\hline Completion Rate & & & $100 \%$ & $99 \%$ & $100 \%$ & $100 \%$ & & & & \\
\hline
\end{tabular}

Example 2 - Cogeco Cable Inc.

\begin{tabular}{|c|c|c|c|c|c|c|c|c|c|c|}
\hline Year & 1995 & $\begin{array}{ll}1996 & 1997 \\
\end{array}$ & 1998 & 1999 & 2000 & 2001 & 2002 & 2003 & 2004 & 2005 \\
\hline \# of shares announced to be repurchased (in thousands) & 277 & 275 & 567 & 250 & 250 & 250 & 250 & 250 & 250 & 250 \\
\hline \# of shares actually repurchased (in thousands) & 49 & 169 & 61 & 31 & 6 & 0 & 0 & 0 & 0 & \\
\hline Completion Rate & $18 \%$ & $62 \%$ & $11 \%$ & $13 \%$ & $3 \%$ & $0 \%$ & $0 \%$ & $0 \%$ & $0 \%$ & \\
\hline
\end{tabular}

Example 3 - Bank of Montreal

\begin{tabular}{|c|c|c|c|c|c|c|c|c|c|c|c|}
\hline Year & 1995 & 1996 & 1997 & 1998 & 1999 & 2000 & 2001 & 2002 & 2003 & 2004 & 2005 \\
\hline \# of shares announced to be repurchase (in millions) & 10.0 & & 7.5 & & 10.0 & 52.0 & & & 15.0 & 15.0 & 15.0 \\
\hline \# of shares actually repurchases (in millions) & 9.2 & & 0.0 & & 7.9 & 52.0 & & & 5.1 & 7.5 & \\
\hline
\end{tabular}

\section{Figure 1-2. Firm-specific examples of share repurchase histories}

Figure 1-2 provides the details for open-market share repurchase programs conducted between 1995 and 2005 for three companies listed on the TSX. In Canada, due to TSX regulations, share repurchase programs are valid for a period of 12 months. Each column of data represents an individual share repurchase program. The first row of each example is the number of shares intended to be repurchased at the announcement of the repurchase program. The second row is the actual number of shares repurchased over the 12 months following the repurchase announcement. The third row is the completion rate of the share repurchase program, calculated as the number of shares actually repurchased (row 2) divided by the target number of shares (row 1). Dundee Realty Corporation (now named Dundee Real Estate Investment Trust) is one of Canada's major real estate management companies; the company focuses on owning, acquiring, leasing and managing mid-sized urban and suburban office and industrial properties in Canada. Cogeco Cable Inc. is one of Canada's largest providers of multimedia video and audio services, high-speed Internet, and digital telephony services. The Bank of Montreal is one of Canada's largest banks with operations in retail and investment banking and personal wealth management. The bank also has minor operations in the U.S. 
We use detailed information of the completion of share repurchase programs of the firms listed on the Toronto Stock Exchange (TSX) to study the possibility that market participants evaluate the credibility of a firm's share repurchase announcement based on the actual completion rates of a firm's past repurchase programs. ${ }^{4}$ We believe that Canadian share repurchase programs provide an optimal venue to examine this issue in two major grounds. First, Canada has a relatively long history of open-market share repurchases programs. ${ }^{5}$ Second, unlike the U.S., Canada has a more transparent regulatory environment and mandatory reporting requirements for open-market share repurchase programs. For example, in the words of Ikenberry et al. (2000):

Canadian data are of particular interest, however, because firms must report each month the number of shares they actually repurchase. This information is summarized by the exchanges and published on a timely basis. Precise, periodic information on repurchase activity does not exist for U.S. firms. Moreover, U.S. reporting conventions even make it difficult to obtain good estimates of overall completion rates (Stephens and Weisbach (1998)). Our unique data allow us to accurately measure program completion rates and examine factors that affect these managerial decisions. ${ }^{6}$

In a sample of 1,507 share repurchase announcements from 1995 to 2005, we find a positive relationship between a firm's prior share repurchase completion rate and the abnormal return observed on the subsequent share repurchase announcement. We

\footnotetext{
${ }^{4}$ In Canada, open-market share repurchase programs are referred to as normal course issuer bids (NCIB) and fixed-price tender offers are referred to as substantial issuer bids. In the remainder of the paper, share repurchase program or simply, repurchase program, will refer to a normal course issuer bid.

${ }^{5} \mathrm{Kim}$ et al. (2004) infer that U.S. disclosure requirements for share repurchases are among the least stringent compared to other countries.

${ }^{6}$ Ikenberry et al. (2000), p. 2375. Parentheses are those of the original authors.
} 
interpret this result as evidence that investors react more positively to the share repurchase announcements of "credible” firms compared to the firms that lack credibility. In addition, consistent with Ikenberry et al. (2001), we report that the average completion rate for Canadian share repurchase programs is approximately 31 percent over the sample period.

Our study most closely relates to Stephens and Weisbach (1998), who examine the market reaction to ex-post completion rates and Chen et al. (2004), who make reference to and control for the ex-post completion rates in their analysis. Similarly, our research also relates to Ikenberry et al. (2000), who study the completion rates for share repurchases of Canadian firms. However, we substantially deviate from these studies and extend this strand of literature, as we specifically examine if a firm's reputation for completing past share repurchase announcements affects the market reaction to the firm's future share repurchase announcements. Our research is groundbreaking in investigating the measurement and the impact of credibility as the past literature is practically mute in this issue.

The remainder of this paper is organized as follows. Section 2 provides a summary of share repurchase regulation and disclosure requirements in Canada. A discussion of the related literature is provided in Section 3. Section 4 provides a description of the sample and discusses the event study methodology. Section 5 presents the results and discusses the variables that are used as a proxy measure for a firm's credibility of its share repurchase announcement. Finally, Section 6 offers concluding remarks. 


\section{CHAPTER 2 \\ OVERVIEW OF CANADIAN SHARE REPURCHASE MARKET REGULATION}

Share repurchase programs are a recent phenomenon and have only been in widespread use in the U.S. since the 1980s. ${ }^{7}$ In 1982, the Securities and Exchange Commission (SEC) adopted Rule 10b-18 which, under certain conditions, provides a safe harbor to repurchasing corporations from litigation relating to price manipulation. Prior to the implementation of Rule 10b-18, U.S. corporations that repurchased shares in the open-market faced the risk of violating the Securities Exchange Act's provisions against price manipulation. Although many countries have recently permitted share repurchase transactions, Canada is one of the only countries outside of the U.S. that has a reasonably long open-market share repurchase history. ${ }^{8}$

Canadian data is also of particular interest because companies are required to report share repurchase activity to the TSX on a monthly basis. In the U.S., firms are not required to disclose or report repurchase activity to regulators and no disclosure system is set up to allow the public to track repurchase activity. In most aspects of the financial

\footnotetext{
${ }^{7}$ See Cook, et al. (2003) for an overview of SEC regulation for open-market repurchases.

${ }^{8}$ Outside of the U.S., share repurchases have only recently become a popular means of distributing cash flows to investors. For many of the world's ten largest stock markets (Japan, the United Kingdom, France, Germany, Canada, Italy, the Netherlands, Switzerland, and Hong Kong), share repurchases were only permitted in the late 1990s. See Kim et al. (2004) for a survey of international open market share repurchase regulations.
} 
markets, the U.S. is seen as a leader in terms of disclosure and market transparency for corporate events such as insider trading activity and equity offerings. However, Kim et al. (2004) find that U.S. regulators do not enforce the same standards with respect to open-market share repurchases. In many other countries, share repurchases are strictly regulated in regards to disclosure and implementation. However, disclosure requirements in the U.S are among the least stringent compared to other major financial markets in the world. Recent studies criticize the current share repurchase regulation in the U.S. and suggest that the SEC should increase the transparency of share repurchase programs in order to promote the efficiency and fairness of financial markets (see Fried, 2005; Cook et al., 2003; Kracher and Johnson, 1997).

Similar to the U.S, the board of directors must approve any share repurchase program in Canada. However, shareholder approval is not needed to initiate a share repurchase program. ${ }^{9}$ Companies must file a notice of intention to the TSX for approval before initiating an open-market share repurchase program. Although the exchange warns that "a notice is not to be filed if the issuer does not have a present intention to purchase shares," no form of disciplinary action is afforded to those firms that do not actually acquire shares. ${ }^{10}$ In addition, it is mandatory for a repurchasing firm to issue a press release indicating that it has applied to the exchange for approval of a share

${ }^{9}$ Kim et al. (2004) report that in many European countries, shareholder approval is required to initiate a repurchase program.

10 See Section 6-501 (6) of Appendix F of the TSX Company Manual (effective January 1, 2005). 
repurchase program. ${ }^{11}$ The press release must include the number of shares sought, the reason for the share repurchase, and the amount of any repurchases in the previous 12month period. The application process is more of a formality that acts as a notification to the exchange that a firm is going to implement a share repurchase program. Accordingly, the application process is usually completed in a limited number of days and firms may commence repurchasing shares two days after receiving approval from the TSX. A share repurchase program expires 12 months after approval is official. The maximum number of shares permitted for repurchase is the greater of (i) 5 percent of shares outstanding, or (ii) 10 percent of the public float. Furthermore, a company cannot purchase more than 2 percent of shares outstanding in a 30-day period. Firms are also restricted from repurchasing shares at a price that is greater than the most recent independent trade price (up-tick rule). ${ }^{12}$ Companies may also use only one broker to make repurchases and the identity of the broker must be reported to the TSX.

In addition to the initial share repurchase application, companies must report to the TSX, on a monthly basis, any repurchase activity within 10 days of the end of each

\footnotetext{
${ }^{11}$ In the majority of share repurchase announcements, the press release indicates that the repurchasing firm has applied to the exchange for approval of a share repurchase program. However, some firms issue a press release indicating the TSX's approval of the share repurchase program in lieu of the press release indicating the application for a repurchase program. The difference between the application date and the date of approval of the share repurchase program is minimal and is usually only one or two days.

12 The TSX defines the independent trade price as the price resulting from transactions that are not related to any share repurchase transactions or to any transaction by insiders of the company.
} 
month. On the third Friday of every month, the TSX publishes a summary containing the status of every current share repurchase program. ${ }^{13}$

${ }^{13}$ See Appendix D, Figure D-1 for an example of a share repurchase summary distributed by the TSX. 


\section{CHAPTER 3 \\ LITERATURE REVIEW}

At the time that Miller and Modigliani (1961) conducted their seminal research on payout policy, open-market share repurchases, in all practicality, did not exist. However, their theory implies that with "perfect markets, rational behavior, and perfect certainty," no difference in firm value should result from different payout policies. Firm value is determined by the underlying cash-flows of the firm, not how the cash-flows are distributed. A repurchase is identical to a dividend payment if, during a share repurchase program, every shareholder sells identical proportions of shares which results in the same proportional control of the firm after the share repurchase is complete. When a firm repurchases shares, the cash used in the repurchase decreases the firm's assets and the shares actually repurchased decreases the firm's equity.

In efficient and perfect markets, Miller and Modigliani’s irrelevance proposition of payout policy may hold. However, in the presence of market imperfections, payout policy may have an effect on firm value. Table 3-1 provides a summary of the empirical findings for short and long-term abnormal returns for firms that announce a share repurchase program. ${ }^{14}$ Empirical studies observe, on average, a 2 to 3.5 percent short-

14 It is common for studies that examine share repurchases that include 1987 in the sample period to exclude announcements made in the fourth quarter of 1987 due to the surge in repurchase announcements following the crash in October of that year. For example, Ikenberry et al. (1995) report 777 firms announced share repurchase programs following the 1987 crash. To put this into perspective, their entire sample of repurchases (continued ...) 
term abnormal return for U.S. companies that announce a share repurchase program. In Canada, researchers find the short-term abnormal return associated with share repurchases to be lower than in the U.S. Canadian repurchasers experience an announcement abnormal return of 0.93 to 1.30 percent. Furthermore, U.S. companies that announce share repurchases display abnormal long-term returns ranging from 8 to 18 percent. In Canada, researchers have found similar magnitudes for long-term postannouncement returns.

\section{(... continued)}

from 1980-1990 (excluding the fourth quarter of 1987) includes 1239 firms. That is, the amount of share repurchases announced in the fourth quarter of 1987 accounts for nearly 40 percent of the total amount of repurchases announced in the ten year period from 1980 to 1990. Furthermore, Comment and Jarrell (1991) "find that repurchases announced during the 9 weeks following the crash are associated with positive returns that are not significantly different from the average return outside this period.” Comment and Jarrell (1991) also suggest the role of credibility in the share repurchase announcement: "We also present evidence that, consistent with signaling theory, investors treat signals of undervaluation based on superior macro-economic information with less credibility than they do signals based on superior firm-specific information.” 
Table 3-1. Summary of empirical findings of share repurchase announcement abnormal returns

\begin{tabular}{lccccc}
\hline Study & Country & Sample Period & Event Window & CAR & $n$ \\
\hline Short-term Abnormal Return & & & & & \\
Ikenberry et al. (2000) & Canada & $1989-1997$ & Month of announcement & $0.93 \%$ & 1,060 \\
Li and McNally (2005) & Canada & $1987-2000$ & -1 to +2 days & $0.73 \%$ & 901 \\
McNally (2002) & Canada & $1988-2000$ & -1 to +4 days & $1.30 \%$ & 396 \\
Vermaelen (1981) & U.S. & $1970-1978$ & -1 to +1 days & $3.62 \%$ & 243 \\
Comment and Jarrell (1991) & U.S. & $1984-1989$ & -1 to +1 days & $2.30 \%$ & 1,037 \\
Ikenberry et. al (1995) & U.S. & $1980-1990$ & -2 to +2 days & $3.54 \%$ & 1,239 \\
Chan et al (2004) & U.S. & $1980-1996$ & -2 to +2 days & $2.46 \%$ & 5,508 \\
Grullon and Michaely (2004) & U.S. & $1980-1997$ & -1 to +1 days & $2.71 \%$ & 4,443 \\
Long-term Abnormal Return & & & & & $14.88 \%$ \\
Ikenberry et al. (2000) & Canada & $1989-1997$ & 2 year & 1,060 \\
McNally (2002) & Canada & $1988-2000$ & 1 year & $9.73 \%$ & 396 \\
Ikenberry et al. (1995) & U.S. & $1980-1990$ & 3 year & $8.69 \%$ & 1,239 \\
Chan et al. (2004) & U.S. & $1980-1996$ & 1 year & $6.68 \%$ & 5,508 \\
Chan et al. (2004) & U.S. & $1980-1996$ & 2 year & $10.97 \%$ & 5,382 \\
\hline
\end{tabular}

Table 3-1 provides a summary of the results from selected studies for the abnormal return on the announcement of a share repurchase program. Results are provided for both short and long-term event horizons. 


\subsection{Why Do Companies Repurchase Stock?}

The literature focuses on five main motivations for share repurchases that may explain the abnormal returns observed on the announcement of repurchase programs. These hypotheses imply that management use open-market share repurchases to: (1) signal to the market in response to a mispricing of the company's stock, (2) disgorge free cash-flow, (3) alter capital structure, (4) increase earnings per share (EPS) and/or offset dilutionary effects of employee stock options, or (5) exploit dividend/capital gains taxation differentials. There is not a single, all-explaining theory to open-market share repurchases. Depending on the circumstances of the repurchasing company, a firm may have a number of motivations to buy back its own stock.

\subsubsection{Signaling and/or undervaluation hypothesis}

Although other theories contribute to the explanation of the observed price performance surrounding share repurchase announcements, the signaling hypothesis has become the predominant theory in explaining the causes and effects of share repurchases (see Vermaelen, 1981; Dann, 1981; Asquith and Mullins, 1986; Comment and Jarrell, 1991; Ikenberry, Lakonishok, and Vermaelen, 1995).

The basis for signaling theory is the existence of asymmetric information between management and investors. In all likelihood, managers will possess privileged information regarding the future performance of the firm. One medium a manager can use to convey any positive, non-public information to the market is through the announcement of a share repurchase program. If managers assess that the firm is undervalued at current stock prices, then they may repurchase shares to the benefit of long-term shareholders. In fact, McNally et al. (2006) find that trades of repurchasing 
firms exhibit firm-specific timing ability since firms tend to actively repurchase during short-run dips in the price of their shares. The authors suggest that this provides evidence that the private information of management leads to asymmetric information between the firm and the market.

Brav et al. (2005), in a survey of 167 financial executives of repurchasing firms, find a strong consensus among company executives that view payout policy as an effective method to convey information to investors. The most popular answer provided by financial executives for the rationale of share repurchases is that "repurchase decisions convey information about our company." ${ }^{15}$ Similarly, in a separate survey, Baker et al. (2003) find that undervaluation is the most cited reason for repurchasing stock among managers. This suggests that signaling is one of the main motivations for corporate managers to repurchase shares.

In most signaling models, there is a cost to firms associated with the signaling action. This cost prevents overvalued firms from mimicking undervalued firms. In the case of dividend initiations or increases, the cost of the signaling mechanism is the dispersion of future cash-flows to shareholders. However, with share repurchases, there is no substantial cost to initiate a share repurchase program. The cost arises when (or if) the firm actually pays out cash in order to acquire shares in the open-market. Unlike a dividend initiation or increase, a share repurchase program is not a firm commitment and

\footnotetext{
15 The question, "Do these statements agree with your company's views," is asked in the survey, along with nine statements as optional answers. "Repurchase decisions convey information about our company to investors" is the most popular response, with 85 percent of respondents selecting agree or strongly agree for the statement.
} 
there is no guarantee that an announcing firm will have to bear any future costs associated with the repurchase program (i.e. acquire shares in the future). Since announcing a repurchase program is costless (in a monetary sense), both undervalued and overvalued firms can announce their intentions to repurchase. Therefore, in an environment of costless signaling, the credibility of the announcement and the reputation of the announcing firm may play a crucial role in the explanation of any abnormal return observed on the date of the announcement. The loss of credibility and reputation from not following through with a share repurchase announcement may be perceived as a cost associated with false signaling.

Much of the research investigating the signaling aspect of share repurchases focuses on determining the firm-specific factors that result in a stronger price response to a share repurchase announcement. Probably the most convincing evidence in favor of the signaling/undervaluation hypothesis is the observation that share repurchase programs are preceded by negative abnormal stock price performance (see Stewart, 1976; Vermaelen, 1981; Asquith and Mullins, 1986; Comment and Jarrell, 1991; McNally, 1999). Furthermore, multivariate analysis confirms a negative relationship between the announcement abnormal return and pre-announcement price performance (see Stephens and Weisbach, 1998; Kahle, 2002; Chan et al., 2004). That is, the market reacts more favorably to a share repurchase announcement when firms experience a price decline prior to the announcement.

Jagannathan et al. (2000) find that firms choosing to increase dividends, rather than repurchase shares, actually experience positive abnormal stock price performance prior to the dividend announcement. Similarly, Baker et al. (2005) find that managers favor share repurchases over specially designated (one-time) dividends when 
management views the firm's stock to be undervalued. This suggests that payout policy is somewhat dependant on management's perception of mispricing in the market. The extant literature argues that if the signaling/undervaluation hypothesis was invalid, we would not expect to see share repurchase announcements linked to stock price movements.

If the signaling hypothesis relies on the existence of information asymmetries between managers and investors, then companies with greater asymmetries should be more inclined to utilize share repurchases as a means to convey information regarding any mispricings to the market. Vermaelen (1981) suggests that "small firms are expected to signal more information when they repurchase their shares." 16 The author suggests that smaller firms may experience higher levels of information asymmetry due to (i) less coverage of smaller firms in the financial media, (ii) lower institutional ownership of small firms, and (iii) less scrutiny by financial analysts. Accordingly, a number of studies find a negative relation between firm size and the abnormal return on the announcement of the repurchase program (see Stephens and Weisbach, 1998; Grullon and Michaely 2002, 2004; Chan, Ikenberry, and Lee, 2004). That is, larger firms, which are less likely to experience information asymmetries, have lower announcement abnormal returns.

\subsubsection{Excess cash distribution and dividend substitution hypothesis}

Managers have incentives to increase the size of the firms under their control by overinvesting in projects that may have negative net present values (NPV), even if these actions are not in the best interests of shareholders. Jensen (1986) suggests that agency

\footnotetext{
${ }^{16}$ See Vermaelen (1981), p.164.
} 
costs, or the costs incurred due to the conflict of interests between managers and shareholders, are particularly severe when a company generates substantial free cashflow. The author suggests that paying out cash to shareholders reduces the resources under management's control, and thus reduces the opportunity for management to overinvest in value destroying projects. Therefore, the abnormal returns observed on the announcement of a share repurchase program may be due to the reduction in free cash (assuming the share repurchase program is actually implemented) and consequently, a reduction in the potential negative affects of agency problems.

Kahle (2002) and Li and McNally (2007) find that the amount of free cash-flow is positively related to the abnormal returns for repurchase announcements. This suggests that the market reacts more favorably to firms that are susceptible to agency problems. Similarly, Grullon and Michaely (2004) find that the share repurchase announcement return is positively related to the overall level of cash in the firm. In addition, the authors find that the relationship between the level of cash and the market reaction to the share repurchase announcement is stronger for firms that are more likely to overinvest (firms with a combination of low book-to-market values and high cash balances). Their findings suggest that firms tend to reduce capital expenditures and cash reserves in the three years following the announcement of a share repurchase program. The authors also find that repurchasing firms experience a decline in systematic risk and cost of capital, which may also explain the positive market reaction to share repurchase announcements.

In the late 1990s, share repurchases replaced dividends as the main method of distributing cash to shareholders (see Figure 1-1). Grullon and Michaely (2002) find that although the nominal value of dividends has increased year-over-year, the growth rate in dividend payments has declined from 15 percent in the 1970s to 4.6 percent in the 1990 s. 
The authors conclude that firms have gradually substituted repurchases for dividends and that the recent increase in share repurchases has come at the expense of lower dividend growth. However, using a sample of Canadian firms, Li and McNally (2007) find that repurchasing firms tend to have higher dividend yields than non-repurchasing firms. The authors suggest that, in Canada, repurchases are not a substitute for dividends. However, their observation does not rule out the substitution hypothesis. It may simply be that dividend paying firms are the most likely candidates for share repurchase programs (i.e. dividend paying firms are likely to have high free-cash flows) and firms may be replacing dividends with repurchases.

Share repurchases and dividends are not perfect substitutes and corporate executives and investors view them very differently. Compared to dividends, share repurchases do not represent the same long-term commitment to returning excess cash to shareholders. The market views dividend payments as a quasi contract and managers have a strong aversion to dividend reductions. Brav et al. (2005) interview corporate executives and find that many managers would pass up positive NPV investment projects before cutting dividends: "today, some executives tell stories of selling assets, laying off a large number of employees, borrowing heavily, or bypassing positive NPV projects, before slaying the sacred cow by cutting dividends.” Eighty-eight percent of respondents strongly agreed that there are negative consequences when dividends are reduced. On the other hand, only 22.5 percent of executives believe that reducing repurchases has negative consequences. Responses to the survey reinforce the view that managers prefer the flexibility of repurchases and dislike the rigidity of dividends. That said, dividends do not seem to be based on residual cash flow, whereas share repurchases seem to follow a residual payout policy. 
Jagannathan et al. (2000) find evidence that aggregate repurchases are evidently more volatile than dividend payments. Consistent with the view that repurchases follow a residual payout policy, temporary cash flows are used to finance repurchases while sustainable cash flows are paid out as dividends. They also find that the standard deviation of operating income for repurchasing firms is about double the standard deviation for dividend increasing firms. Again, this suggests that cash flows for repurchasing firms are more uncertain than they are for dividend increasing firms. They conclude that share repurchases do not appear to be replacing dividends, but rather repurchases serve as a role for paying out short-term cash flows to investors.

\subsubsection{Increasing earnings per share and/or offset dilution of employee stock options}

The most cited justification for share repurchases, especially among corporate executives and the financial press, is the belief that repurchases increase EPS by decreasing the number of shares outstanding. ${ }^{17}$ In their survey of corporate executives, Brav et al. (2005) find that increasing earnings per share is the second most significant factor affecting a company's share repurchase decision. ${ }^{18}$ Furthermore, a number of

${ }^{17}$ A recent column, "Big Companies Put Record Sums Into Buybacks; Repurchases Aim to Bolster Shares but They Also Signal Hesitancy to Invest in Growth" (Wall Street Journal, June 12, 2006, p. A.1), reflects the common belief of the media in the causational relationship between share repurchases and accretive EPS.

${ }^{18}$ Seventy-six percent of respondents indicate "increasing earnings per share" as an important or very important factor in the share repurchase decision. The most popular factor, among the ten offered in the survey, is "whether our stock is a good investment relative to other available investments" (78.9 percent indicate it is an important or very important factor). The third most popular factor is "offsetting the dilutionary effect of stock option plans or other stock programs" (67.6 percent indicate it is an important or very important factor). 
corporate executives interviewed could cite the precise numerical estimates of EPS given their repurchase program and knew what EPS would be if no shares were repurchased.

If share repurchases reduce the number of shares outstanding and, assuming net income remains unaffected, it is possible for EPS to grow faster than net income. However, there are a couple of factors that may negate the perceived relationship between repurchases and EPS growth. First, a share repurchase will increase earnings only if the funds designated for the repurchase would otherwise fail to earn the firm's cost of capital, that is the firm's investment opportunity set does not include any positive NPV projects. If this is the circumstance, then investing in the company's own stock is a better use of funds than other alternative investments. If positive NPV investments exist, then executing a share repurchase may actually destroy shareholder value.

Second, even if a company repurchases shares, it does not necessarily translate into a lower number of shares outstanding at the end of the repurchase program. While a firm is repurchasing shares, it may also be issuing shares to fulfill employee stock options. Studies have shown that the number of shares outstanding actually increases for many repurchasing firms. Li and McNally (2007) find that for Canadian repurchasers the average number of shares outstanding actually rises by 4.7 percent, compared to a control sample of non-repurchasing firms that experience an increase of 10.0 percent in shares outstanding over the same time period. ${ }^{19}$ This implies that although most share

${ }^{19}$ In Canada, securities trading law prohibits the sale of securities by a company during a share repurchase program (Ontario Securities Act, Part XX, Section 94. (8)). Therefore, any increase in the number of shares outstanding must be the result of the exercise of employee options or the result of the conversion of other convertible securities. 
repurchase programs do not decrease the number of shares outstanding, repurchases slow the rate of dilution that is caused by the redemption of employee stock options. Bens et al. (2003) and Kahle (2002) also conclude that many repurchase programs are used to offset the dilution effects of the exercise of employee stock options. Brav et al.’s (2005) findings support this argument when their survey of corporate executives finds that the third most influential factor in the repurchase decision is to offset the dilutionary effect of employee stock option plans. ${ }^{20}$

Hribar et al. (2004) report that only 19.9 percent of repurchasing firms increase EPS by one cent or more. However, their results suggest that firms may use repurchases to compensate for earnings shortfalls. Accretive repurchases occur more frequently to firms that had negative pre-repurchase earnings surprises and accretive repurchasing firms are less likely to meet or exceed expected earnings in the absence of a stock repurchase compared to a matched sample of non-repurchasing firms. This suggests that repurchases are sometimes used to manage EPS in order to meet analysts' consensus for earnings forecasts.

\subsubsection{Capital structure adjustment}

Altering capital structure is often cited in the literature as a motivation for firms to repurchase shares. Corporations can use share repurchases to increase debt-to-equity ratios by lowering the total amount of equity (lowering the number of shares outstanding). However, the empirical evidence in support of the capital structure adjustment hypothesis is less convincing. First, the size of open-market share repurchase

\footnotetext{
${ }^{20}$ See footnote 18.
} 
programs are usually small (around 5 percent of shares outstanding). Chan et al. (2004) report that firms that are most likely to be motivated to repurchase shares in order to alter capital structure (i.e. firms with low leverage compared to the industry average), do not have larger abnormal returns on the announcement of a share repurchase program. Furthermore, Brav et al. (2005) find that only 28.2 percent of corporate executives report that changing debt-to-equity ratios is an important factor when deciding to repurchase shares (a relatively low rating compared to the top three most popular responses). ${ }^{21}$ The empirical evidence points to more relevant factors contributing to the share repurchase decision, such as the signaling or free-cash flow hypotheses.

\subsubsection{Tax benefit of repurchases versus dividends}

The tax benefit that arises due to the differential treatment of dividends versus capital gains is often cited as a reason for the benefits of share repurchases over dividends. However, recent legislation in both Canada and the U.S. has made dividends more competitive from a tax perspective. Furthermore, many institutions and corporations do not pay taxes on dividends. Brav et al. (2005) find that executives indicate that tax implications are a minor consideration in the repurchase decision and do not play a primary role in the payout policy decision. However, the narrowing of the tax differential over the last 15 years may explain the dampened announcement returns over the last few years. Grullon and Michaely (2002) find that abnormal returns on repurchase announcements decrease after the enactment of the Tax Reform Act of 1986, which significantly reduced the tax differential between dividends and capital gains. The

\footnotetext{
${ }^{21}$ See footnote 18.
} 
authors also find that the abnormal return on the announcement of a share repurchase program is positively related to the tax differential between the top marginal tax rate on ordinary income and the top marginal tax rate on capital gains. This evidence suggests that taxes have a minor effect on the market reaction to share repurchase announcements.

\subsection{Actual Acquisition of Shares in Repurchase Programs}

The extant literature has attempted to estimate the actual number of shares repurchased in share repurchase programs. In addition, studies attempt to identify factors that lead to more intensive repurchasing activity. The literature also examines the effect of actual share repurchase transactions on the prices and liquidity of the firm's stock.

\subsubsection{Estimation of share repurchase completion rates}

Share repurchases are not a firm commitment and companies are not obligated to acquire shares after the share repurchase announcement. Stephens and Weisbach (1998) is one of the first studies to estimate share repurchase completion rates for a sample of U.S. share repurchase announcements. Recall that U.S. firms are not required to report share repurchase activity to a regulatory body. Therefore, the authors must estimate the number of actual shares repurchased by measuring either (i) changes in shares outstanding measured using data from the Center for Research in Security Prices (CRSP), or (ii) cash-flow data from Compustat associated with share repurchase activity. The estimate of the actual number of shares repurchased varies depending on the source of the data (i.e. CRSP or Compustat) and the different assumptions regarding the market price 
of the share repurchase transactions. ${ }^{22}$ The authors find that the average size of a repurchase program is for 7 percent of total shares outstanding. For the 36 months following the repurchase announcement, the average firm repurchases between 74 to 82 percent of the initial number of shares stated in the repurchase announcement. ${ }^{23}$ For the 12-month period following the announcement, the authors find a completion rate ranging from 46 to 70 percent. However, there is substantial variance in the completion rates. Fifty-seven percent of firms repurchase more than 100 percent of the announced number of shares in the three years following the announcement. However, 17 percent of firms repurchase less than 20 percent of the announced number of shares over the same time horizon. In the U.S., firms do not have to announce the intended time horizon of their share repurchase programs. The relatively high completion rates may be due to the

\footnotetext{
${ }^{22}$ The exact execution price of each share repurchase transaction is unknown. Therefore, the authors assume that companies repurchase shares at the average stock price over the period of the share repurchase program. The completion rate is calculated by first estimating the number of shares repurchased by dividing the total dollar value spent on repurchases (Compustat's Purchases of Common and Preferred Stock, data item \#115) by the average share price over the 3-year repurchasing period. The completion rate is then calculated by dividing the estimate of the actual number of shares repurchased by the number of shares targeted for repurchase at the time of the share repurchase announcement.

${ }^{23}$ Stephens and Weisbach's (1998) completion rate estimate assumes that companies halt the acquisition of shares once the share repurchase program has acquired 100 percent of the target number of shares. However, in their sample many firms repurchase a substantial greater number of shares than the target stated at announcement. If this assumption is relaxed, the average completion rate is 266 percent for the three years following the announcement. Using a similar methodology, Jagannathan and Stephens (2003) also find high average completion rates in the range of 100.7 to 134.7 percent in the two years following the repurchase announcement.
} 
assumed 3-year length of the acquisition period, which may be longer than most firms' desired acquisition periods.

Ikenberry et al. (2000) study the completion rates for share repurchases of Canadian firms. Since Canadian firms must report repurchase activity to the TSX, the exact number of shares actually repurchased is known and it is not necessary to estimate actual repurchases using cash-flow or shares outstanding data. In Canada, companies must apply for approval of a share repurchase program before acquiring any shares. Upon approval, the share repurchase program expires in 12 months and companies must reapply for approval before acquiring additional shares. The authors report that the average repurchase program targets 5.22 percent of shares outstanding. They find that the average completion rate for share repurchase programs is 28.6 percent for the 12 month period following the repurchase announcement, with about half of all repurchase activity occurring within 3 months of the announcement date. Only 14.5 percent of firms repurchase a substantial number of the announcement target (75 to 100 percent completion rates). Surprisingly, the authors find that 22.3 percent of firms fail to acquire any shares during the repurchase program. Approximately 60 percent of firms acquire less than 25 percent of the targeted number of shares in the repurchase program.

Due to the lack of regulation and disclosure requirements and the unclear durations of repurchase programs in the U.S., direct comparisons of completion rates between Canada and the U.S. is not very meaningful. U.S. completion rates must be estimated using cash-flow data or changes in the number of shares outstanding, whereas the actual number of shares repurchased by Canadian firms is reported directly to the TSX. 


\subsubsection{Factors that determine share repurchase completion rates}

Numerous studies have attempted to identify factors that affect the number of shares actually acquired in share repurchase programs (see Stephens and Weisbach, 1998; Ikenberry et al., 2000; Kahle, 2002; Cook et al., 2004; McNally et al., 2006). All of the studies find a negative relationship between past returns and share repurchase activity. That is, companies actively repurchase shares following abnormal stock price declines and are less inclined to repurchase when prices have risen. If prices rise after a share repurchase announcement, the incentive to repurchase decreases (i.e. the firm's stock is less "undervalued") and firms may not follow through on their original share repurchase intentions. This conditional behavior provides evidence that managers strategically repurchase shares when they perceive their stock to be temporarily undervalued and refrain from repurchasing when stock prices are relatively high.

Stephens and Weisbach (1998) and Kahle (2002) find that share acquisitions are positively correlated with cash-flow, suggesting that firms that have excess cash are more likely to repurchase shares. In addition, Kahle (2002) suggests that share repurchase activity is greater for firms that have outstanding employee stock options.

\subsubsection{Effect of share repurchases on liquidity and prices}

McNally et al. (2006) and Cook et al. (2004) find that companies utilize limit orders when repurchasing shares, suggesting that firms repurchase shares in an attempt to provide liquidity and buffer sell-side pressure in order to provide price support for falling stock prices. McNally et al. (2006) find that, on average, share repurchases for TSX listed firms account for 12.25 percent of total trading volume during the repurchase program period. 
Using survey results from 64 U.S. firms ${ }^{24}$, Cook et al. (2004) find that, on average, repurchases for firms listed on the New York Stock Exchange (NYSE) represent 6.6 percent of total trading volume over the course of the entire repurchase program while NASDAQ repurchases represent 10.4 percent of aggregate trading volume. On actual repurchasing days, NYSE firms' repurchases account for 19.48 percent of average daily trading volume and NASDAQ repurchases account for 33.03 percent daily trading volume. The average program length varies from 195 days (with 88 days of repurchasing) for NYSE companies and 116 days (with 16 days of repurchasing) for NASDAQ listed companies. Firms also wait an average of 17 days following the announcement of a repurchase program to make their first repurchasing trade.

A number of studies have examined the effect of share repurchases on liquidity, as measured by the bid-ask spread. Cook et al. (2004) find that share repurchase activity increases liquidity, resulting in narrower bid-ask spreads on days surrounding share repurchase transactions. However, Brockman and Cheung (2001) argue that share repurchases cause a widening of the bid-ask spread due to information asymmetries and informed trading by repurchasing firms in Hong Kong. Accordingly, Barclay and Smith (1988) also report that share repurchases result in higher bid-ask spreads for U.S. firms.

${ }^{24}$ Cook et al. (2004) sent questionnaires to 478 repurchasing firms identified in SDC's Merger and Acquisitions Database between 1993 and 1994, of which 64 responded. The questionnaire asked firms to provide detailed information of their share repurchase programs, including the date (as well as the intraday time of the trade), size, and price of every share repurchase transaction. In addition, the firms were also asked to disclosure the identity of the broker used to repurchase shares. 


\section{CHAPTER 4 \\ SAMPLE CONSTRUCTION AND METHODOLOGY}

The initial sample consists of all open-market share repurchases initiated between December 1, 1994 and December 31, 2005 for companies listed on the Toronto Stock Exchange (TSX). Once a month, the TSX publishes the current status of all share repurchase programs in the Daily Record. ${ }^{25}$ Each share repurchase summary provides the issuer's name, expiry date of repurchase program, maximum number of shares authorized for repurchase, percentage of total shares outstanding targeted for repurchase, type of security to be repurchased, number of shares repurchased in the previous month, and total number of shares repurchased to date.

During the sample period, there were a total of 3,086 repurchase programs initiated. We exclude all repurchases that are for income trust units (320), preferred shares (34), debentures (60), warrants (15), and notes (4). For firms announcing concurrent repurchase programs for more than one type of common share (i.e. dual-class voting share structures), we include the repurchase program for subordinate voting shares

\footnotetext{
25 The Daily Record is a publication distributed by the TSX at the end of every trading day that includes the statistical highlights for the day's trading. On the third Friday of every month, the TSX includes a section on "Normal Course Issuer Bids" that includes information on the status of all current share repurchase programs. As of 2005, the TSX has also included share repurchase summaries in their monthly publication, the TSX EReview. See Appendix D for an excerpt of the share repurchase summary published in the Daily Record.
} 
but exclude any repurchase programs for multiple voting shares (165). ${ }^{26}$ Furthermore, due to mergers, acquisitions, bankruptcies, and name changes, another 30 companies were unidentifiable in the CFMRC database.

Security price data is obtained from the Canadian Financial Markets Research Center (CFMRC) Summary Information Database. ${ }^{27}$ For cross-sectional analysis, we obtain accounting data from Compustat. Share repurchase announcement dates are obtained from Security Data Corporation's SDC Platinum: Non-U.S. Mergers and Acquisitions database. The SDC database does not include all of the share repurchase announcements that are reported in the Daily Record. For repurchase programs not found in the SDC database, we obtain announcement dates from the original press release for the share repurchase. Press releases are obtained from the System for Electronic Document Analysis and Retrieval (SEDAR). ${ }^{28}$ We are unable to determine announcement dates for a further 177 repurchase programs. Therefore, our initial

\footnotetext{
${ }^{26}$ For firms that conduct concurrent repurchase programs for both subordinate voting shares and multiple voting shares, the exclusion of subordinate voting repurchase programs prevents the double counting of these firms' repurchase programs into our sample. Furthermore, the market for multiple voting shares is often less liquid compared to the market for subordinate voting shares.

${ }^{27}$ The CFMRC database is the Canadian equivalent to the Center for Research in Security Prices (CRSP) U.S. Stock Database. Name changes, takeovers and acquisitions, and amalgamations are identified using the FPinfomart - Predecessor \& Defunct database, which is maintained in coordination with the Financial Post, one of Canada's leading financial newspapers.

${ }^{28}$ SEDAR is the Canadian equivalent to the Electronic Data Gathering, Analysis, and Retrieval system (EDGAR) for U.S. companies.
} 
sample consists of 2,281 common share repurchase programs initiated by 752 different companies. $^{29}$

The construction of the data set used in this study is a formidable contribution in itself. No electronic database exists that contains historical Canadian share repurchase data. Therefore, a database of share repurchase programs was compiled from the original hard-copies of the TSX's Daily Record. ${ }^{30}$ The collection of the data required a substantial investment of time, taking close to three months (and approximately 500 working hours) to record over three thousand individual share repurchase programs and the associated data for each program. Each entry was carefully scrutinized at least twice. Furthermore, additional time was devoted to data verification and a comprehensive audit was performed to identify and investigate any erroneous share repurchase entries. We identify any outliers in the data (e.g. share repurchase programs with completion rates greater than 100 percent) and investigate whether the data recorded for the repurchase program is the actual data contained in the Daily Record. We also compare the

29 The SDC database includes 1,551 share repurchase announcements. For the remaining 730 share repurchase programs, we obtain announcement dates from SEDAR.

${ }^{30}$ Original copies of the Daily Record are obtained from the library at the University of Alberta. The library has original hard-copies of the Daily Record dating back to January of 1996. Therefore, our sample begins with the December, 1995 share repurchase summary report that was published on the third Friday of the following month, or the January 19, 1996 edition of the Daily Record. However, the share repurchases that expired in December, 1995 commenced twelve months prior to the expiry dates and were announced in December of 1994. Therefore, our sample consists of share repurchases announced between December, 1994 and December, 2005. The University of Alberta has pre-1996 copies of the Daily Record available in microfilm. Unfortunately, the share repurchase summaries are illegible in the microfilm format and we were unable to include pre-1996 copies of the publication into our sample. 
announcement dates for share repurchase transactions recorded in the SDC database to the corresponding dates that are implied in the TSX Daily Record and investigate any differences by referring to the actual share repurchase announcement press release.

Many firms announce more than one share repurchase program over the sample period. Figure 4-1 provides the frequency of the number of share repurchases over the sample period for each firm. The majority of companies in the sample (272 firms or 36 percent of firms) announce only one share repurchase program over the sample period. The number of firms that announce multiple repurchase programs steadily declines, from 149 firms, or 20 percent of firms, that conduct two repurchase programs to 3 firms that conduct eleven repurchase programs (or one repurchase program in every year of the sample period). The average firm that conducts multiple share repurchase programs allows 473 days to lapse before initiating another share repurchase program. Our sample includes many firms that announce consecutive repurchase programs: 1,390 of the 2,281 repurchase announcements, or 61 percent, occur within 750 days (approximately 2 years) and 896, or 39 percent of repurchases, occur within 375 days. This is similar to Jagannathan and Stephens (2003) who document that 47.5 percent of U.S. repurchasers announced at least two repurchase programs within their five-year sample period. 


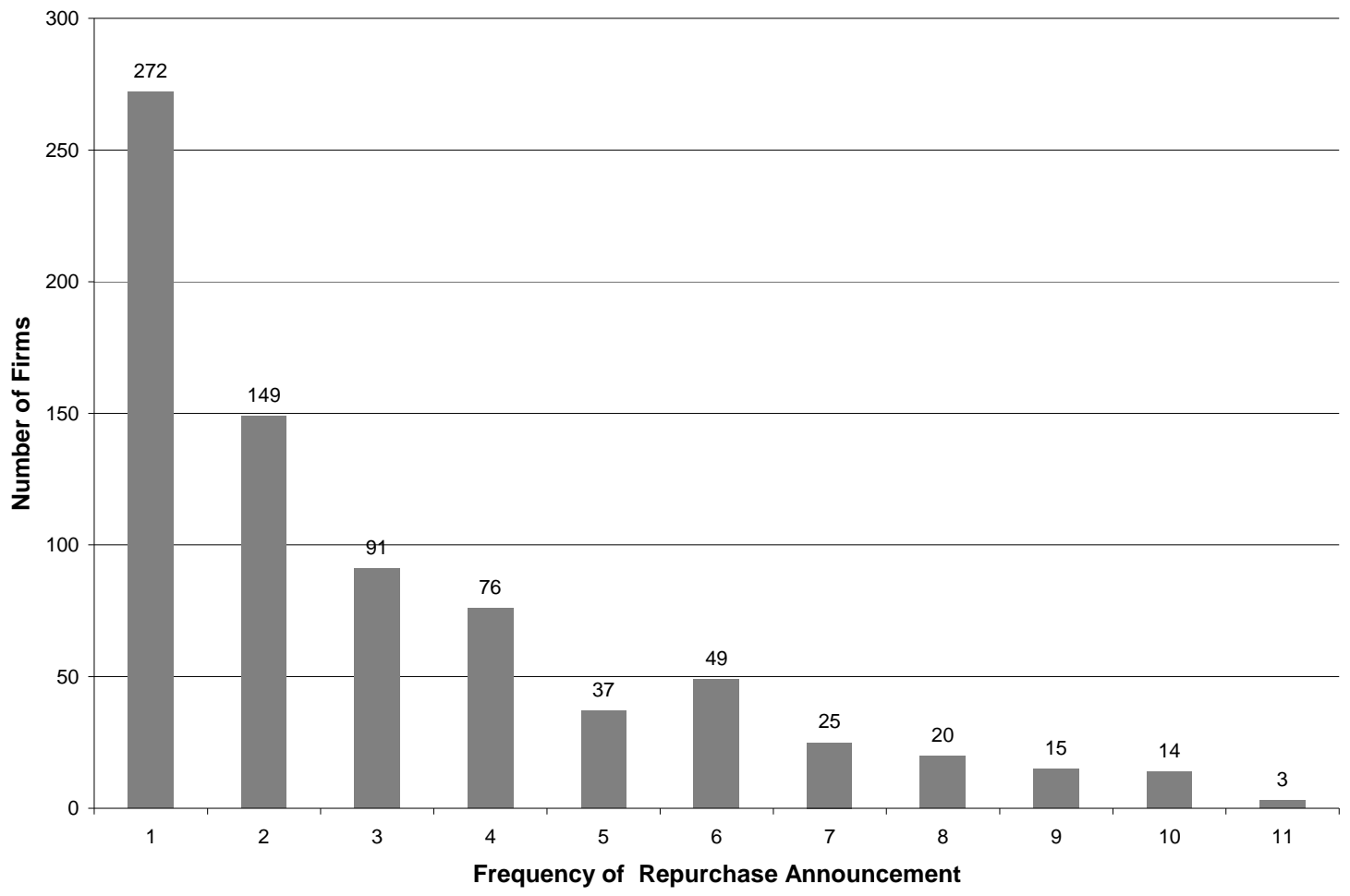

Figure 4-1. Frequency of share repurchase announcements

Figure 4-1 presents a histogram of the frequency of share repurchases for each firm over the sample period, December of 1994 to December of 2005. The frequency of announcements is the number of times an individual firm announces a share repurchase program over the sample period. 


\subsection{Share Repurchase Activity and Completion Rates}

The number of Canadian share repurchase announcements varies substantially over time. Figure 4-2 reports the number of share repurchase announcements for each year of the sample. Repurchase announcements peaked in 2000 at 315, but have declined in recent years to under 200 announcements in 2005. Figure 4-2 also provides the target number of shares announced for repurchase programs and the actual number of shares acquired in the 12 months following the announcement. Although the number of share repurchase announcements (represented by the solid line in Figure 4-2) has decreased since 2003, the target number of shares (represented by the shaded bar in Figure 4-2) actually increases. In fact, the number of shares targeted for repurchase reaches a maximum of 887 million shares in 2005, even though the number of announcements in 2005 is only 172. Perhaps this is a result of more large-cap firms initiating repurchase programs and small-cap firms tending not to repurchase as frequently relative to earlier years in the sample. Table 4-1 indicates that the mean market capitalization of announcing firms is larger in the later years of the sample.

The completion rate for Canadian share repurchases is surprisingly low. The average completion rate for equity share repurchases initiated between December of 1994 to December of 2004 is 31.3 percent (median of 18.3 percent) over the twelve months following the repurchase announcement. ${ }^{31}$ For comparison, our findings are very similar

\footnotetext{
${ }^{31}$ Although share repurchase announcements occurring in 2005 will be used in the event study and multivariate analysis, it is not possible (at the time of writing) to calculate the completion rates of repurchases announced in 2005 because many of the repurchase programs have not yet expired.
} 
to the 28.6 mean completion rate reported by Ikenberry et al. (2000) for a sample of Canadian firms announcing share repurchases between 1989 and 1998. However, the completion rates for Canadian repurchases are lower than the estimated completion rates for U.S repurchases. Stephens and Weisbach (1998) find completion rates of 46 to 70 percent over the one year following the repurchase announcement. Not surprisingly, the completion rate varies over time. As Table 4-1 indicates, the mean completion rate varies from a low of 19 percent in 2003 to a high of nearly 40 percent in 1999. 


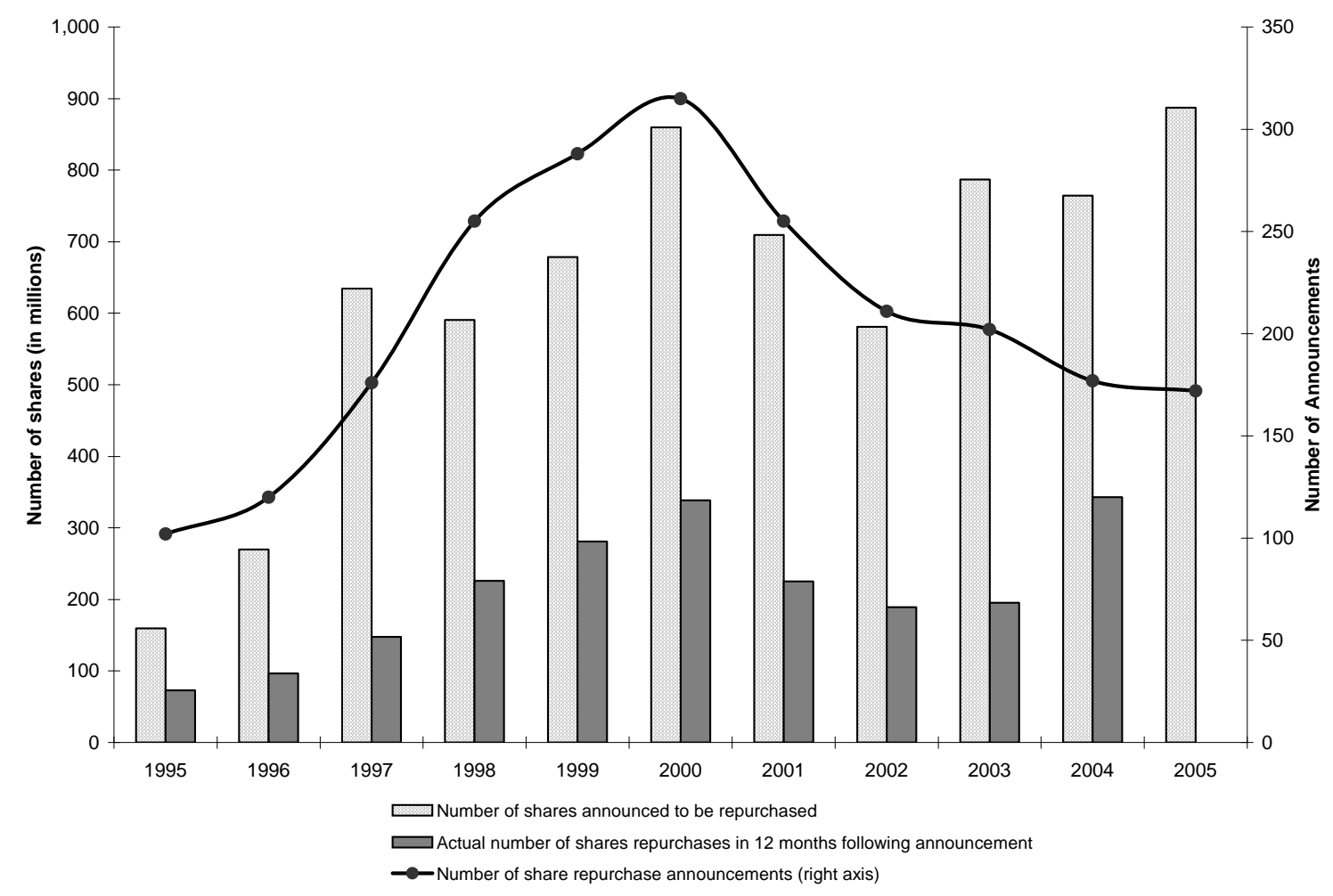

Figure 4-2. Share repurchase activity in Canada between 1995 and 2005

Number of shares announced to be repurchased per year and the number of shares actually repurchased over the subsequent year of the announcement (represented by vertical bars). Number of share repurchase announcements per year (represented by line) is measured on the right axis.

Table 4-1. Share repurchase announcements, completion rates, and average size of announcing firms

\begin{tabular}{cccc}
\hline Year & $\begin{array}{c}\text { Number of } \\
\text { Announcements }\end{array}$ & $\begin{array}{c}\text { Mean } \\
\text { Completion } \\
\text { Rate }\end{array}$ & $\begin{array}{c}\text { Mean Market } \\
\text { Capitalization of } \\
\text { Repurchasing Firms }\end{array}$ \\
\hline 1995 & 102 & $37.2 \%$ & $1,189.7$ \\
1996 & 120 & $35.5 \%$ & $1,641.3$ \\
1997 & 176 & $32.9 \%$ & $1,446.7$ \\
1998 & 255 & $37.4 \%$ & $1,293.4$ \\
1999 & 288 & $39.6 \%$ & $1,714.5$ \\
2000 & 315 & $36.1 \%$ & $1,442.1$ \\
2001 & 255 & $25.1 \%$ & $1,705.7$ \\
2002 & 211 & $22.4 \%$ & $2,484.3$ \\
2003 & 202 & $19.4 \%$ & $2,962.4$ \\
2004 & 177 & $26.5 \%$ & $4,117.6$ \\
2005 & 172 & & $4,339.2$ \\
Entire Sample & 2281 & $31.3 \%$ & $2,212.5$ \\
\hline
\end{tabular}

* (in millions of dollars) 
Figure 4-3 provides the distribution of the completion rates of share repurchase programs. Surprisingly, 424 repurchasing programs (or approximately 20 percent of the sample) fail to repurchase any shares in the twelve months subsequent to the announcement of the program. The majority of firms, 662 (or 31 percent of the sample), repurchase between 0 and 20 percent of the targeted amount of shares stated at announcement. Approximately 52 percent of firms repurchase less than 20 percent of the number of shares stated at announcement. Only 289 firms (14 percent of sample) repurchase between 80 and 100 percent of the announced number of shares. Eight firms repurchase more shares than stated at announcement, however the excess repurchases are very minimal in most cases (the highest completion rate in the sample is 165 percent). 


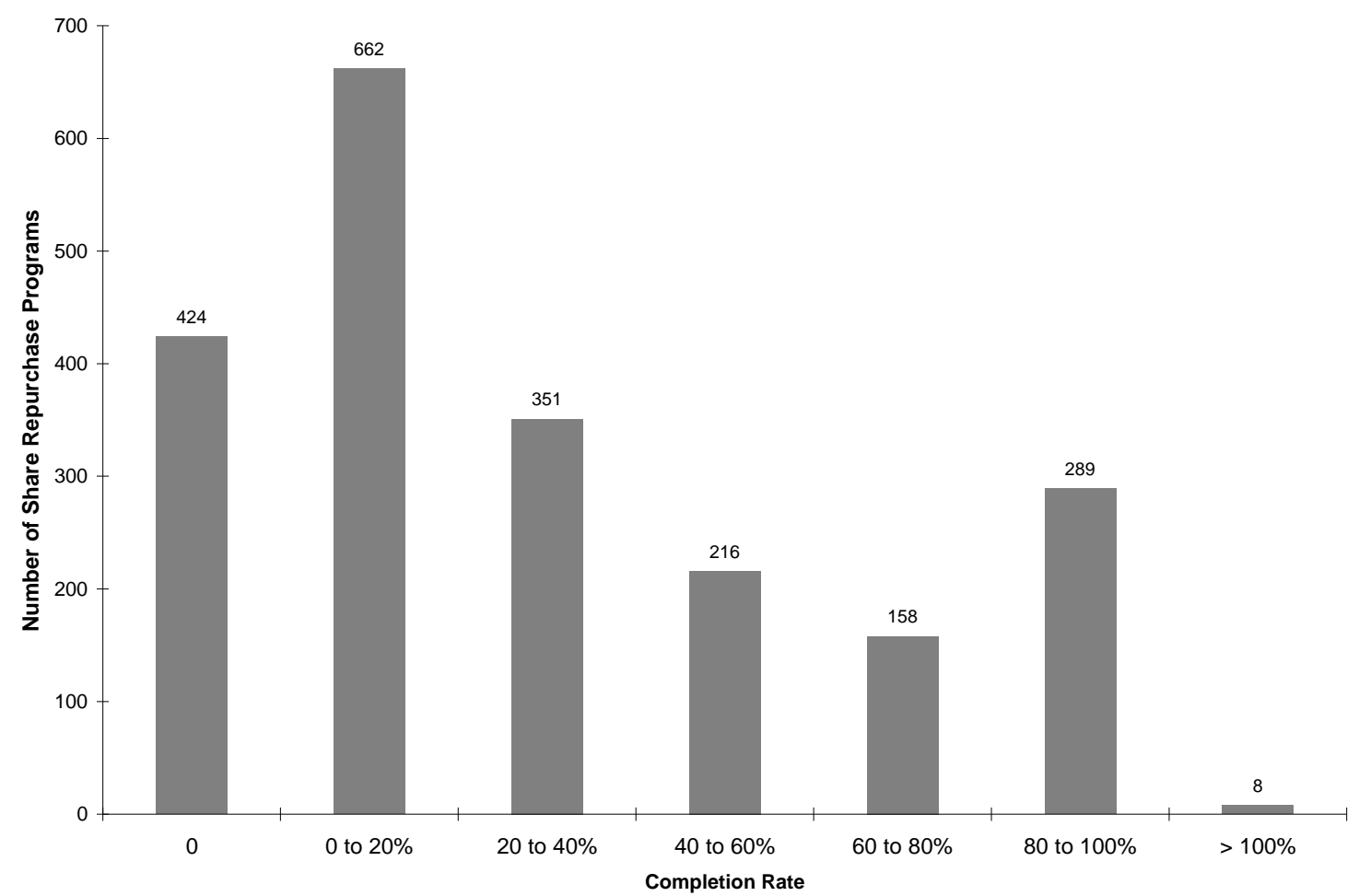

Figure 4-3. Histogram of distribution of share repurchase completion rates

Figure 4-3 illustrates the distribution of the completion rates for share repurchase programs included in our sample. 


\subsection{Event Study Methodology}

In order to determine whether the market evaluates the informational content of a share repurchase based on the credibility of the share repurchase announcement, a measurement of the price response to the announcement is needed. This study relies on standard event-study methodology to calculate the abnormal return on the announcement of share repurchase program. We use the single factor market model of Brown and Warner (1985). According to the market model, the abnormal return on a given trading day is calculated as:

$$
A R_{i, t}=R_{i, t}-\hat{\alpha}_{i}-\hat{\beta}_{i} R_{m, t}
$$

where $A R_{i, t}$ is the abnormal return for firm $i$ on day $t, R_{i, t}$ is the return for firm $i$ on day $t$, $R_{m, t}$ is a proxy measure for the return on the market portfolio (CFMRC value weighted index), and $\hat{\alpha}_{i}$ and $\hat{\beta}_{i}$ are OLS estimates of the market model parameters from equation (4.2).

$$
R_{i, t}=\hat{\alpha}_{i}+\hat{\beta}_{i} R_{m, t}+\hat{\varepsilon}_{i, t}
$$

Equation (4.2) is estimated over a 250 day estimation period. If we define day 0 as the announcement date of the share repurchase program and day -1 as the trading day before the announcement period, then the estimation period includes days -270 to -21 .

For a security to be included in the event-study sample, some restrictions are placed in order to ensure that our estimates are robust. First, a security must not be missing any returns in the event window. We use a five-day event window that includes 
days -2 to +2 , relative to the announcement day. ${ }^{32}$ In the initial sample of 2,281 repurchase announcements, 705 observations are missing returns in the event window. The relatively large number of firms that are missing returns in the event window is a result of the high number of thinly traded stocks listed on the TSX. The second condition for inclusion in the event-study sample is for the repurchasing firm to have at least 100 trading days of returns in the estimation period (days -270 to -21). An additional 69 observations violate this condition and are excluded from the sample. The final sample of share repurchase announcements included in the event-study includes 1,507 observations. $^{33}$

To measure abnormal return around the announcement date, the cumulative abnormal return (CAR) is calculated over the event window as follows:

$$
\operatorname{CAR}_{i}(-2,+2)=\sum_{t=-2}^{+2} A R_{i, t}
$$

To test the null hypothesis that the CAR is equal to zero, we compute the test statistic proposed by Brown and Warner (1985):

\footnotetext{
${ }^{32}$ We use a multi-day event window in order to account for possible information leakages that may occur before the announcement day.

${ }^{33}$ For a robustness check, we apply different estimation and event windows and different conditions regarding missing data in the estimation window. We also calculate the abnormal return using the market adjusted method (company return less market return) that does not require OLS estimation of the market model parameters. The results using different event-study methodologies do not differ substantially from the results presented in the main body of the paper. Refer to the Section 5.4 - Robustness Tests for a description and results for the different event-study methodologies.
} 


$$
t=\frac{\sum_{t=-2}^{+2} \overline{A R_{t}}}{\sqrt{\sum_{t=-2}^{+2} \hat{S}^{2}\left(\overline{A R_{t}}\right)}}
$$

where

$$
\overline{A R_{t}}=\frac{\sum_{i=1}^{N} A R_{i, t}}{N},
$$

and

$$
\hat{S}^{2}\left(\overline{A R_{t}}\right)=\sqrt{\frac{\sum_{t=1}^{T}\left(\frac{\left.\sum_{A R_{t}}-\frac{\sum_{t=1}^{T} \overline{A R_{t}}}{T}\right)^{2}}{T-2}\right.}{T-2}}
$$

where $N$ is the number of firms in the sample and $T$ is the number of days in the estimation period. Under the null hypothesis of no abnormal price performance, the test statistic in (4.4) is distributed Student-t with T-2 degrees of freedom.

\subsection{Short-term Repurchase Announcement Abnormal Returns}

For the overall event-study sample, the average CAR for the 5-day event window surrounding the announcement date is 1.79 percent $^{34}$ and is significant at the 1 percent level. Table 3-1 of Chapter 3 presents the results of past studies for the announcement CAR. The average abnormal announcement return in our sample is slightly higher than the announcement abnormal returns found in previous studies on Canadian share repurchase announcements. Ikenberry et al. (2000) find a 0.93 percent abnormal return in

\footnotetext{
34 The median CAR is 0.79 percent. Other variations to the event study methodologies produce results similar to those reported. See Section 5.4 - Robustness Tests, for a detailed explanation of the different tests performed to check the robustness of the results.
} 
the month of the repurchase announcement. Similarly, McNally (2002) finds a 1.30 percent CAR for the five days surrounding the repurchase announcement. The difference between our results and those of previous studies may be a result of different methodologies and the different time frames of the studies (our study uses more recent data). 
CHAPTER 5

ANNOUNCEMENT CREDIBILITY AND REPUTATIONAL EFFECTS

A number of different hypotheses have been proposed in an attempt to explain the abnormal price performance surrounding share repurchase announcements. However, none of these hypotheses directly account for credibility and reputational effects when, in all likelihood, the credibility of the announcement plays a crucial role in the evaluation of the informational content of the repurchase announcement. As our study illustrates, the majority of firms fail to acquire the number of shares specified in the share repurchase announcement and one in five repurchasing firms fail to acquire any shares at all. With share repurchases, the distribution of corporate cash flows to investors is conditional on the firm actually repurchasing shares.

We examine the possibility that market participants evaluate the credibility of a firm's share repurchase announcement based on the actual completion rate of the firm's previous share repurchase program. The main hypothesis of this thesis is that we expect credible firms to experience higher abnormal returns upon the announcement of a share repurchase program compared to firms that lack credibility. 
The economics literature on game theory offers some insight into the role that reputation and credibility play in the presence of asymmetric information. Shapiro (1983) models reputation in a buyer/seller scenario and Sobel (1985) in a signaling/communicating framework. Both authors find that once established, a credible reputation is valuable. Sobel (1985) elaborates in the following passage:

This paper attempts to model situations that arise when someone is uncertain about whether to trust the people he deals with. In this context, reputations for reliability are valuable. ... If an agent is uncertain about the motives of someone upon whom he must depend, either to provide information or make decisions, then the extent to which he trusts the other will be based on the partner's earlier actions. ${ }^{35}$

In a buyer/seller experimental context, DeJong et al. (1985) find evidence that in a multiperiod setting, sellers establish a reputation with buyers based on prior dealings. In turn, buyers use this reputation to estimate the quality of the seller's product and set prices accordingly.

However, the literature in financial economics is somewhat silent in terms of the role of reputation and credibility for corporate finance events. Only a handful of studies have mentioned credibility as a possible factor related to announcement abnormal returns (see Oded (2005), Chan et al. (2004), and Stephens and Weisbach (1998)). None of these studies have examined the empirical data to verify the role, if any, that reputation plays in the stock price response to a share repurchase announcement. Our research is groundbreaking in empirically investigating the relationship between announcement credibility and abnormal returns.

${ }^{35}$ Sobel (1985), p. 557 and p. 570. 
Stephens and Weisbach's (1998) research offers some insight into measuring credibility. Their study measured the completion rates of share repurchase programs by estimating the number of shares actually acquired in the 24 months following the repurchase announcement. In a regression of announcement abnormal returns, they include their measure of actual repurchases as an explanatory variable. The authors explain their reasoning:

If investors have information about what fraction of the announced target they anticipate will actually be repurchased, we would expect them to incorporate this information into their behavior. Thus, to the extent that investors can forecast the firm's future share repurchases, the announcement period abnormal returns should be related to actual share repurchases. ...For example, some firms might announce repurchase plans, but have expected cash flows too low to complete the programs; in this case we would observe a cross-sectional relation between announcement abnormal returns and subsequent repurchases. ${ }^{36}$

The authors find a positive relation between announcement abnormal returns and actual subsequent repurchases. They also suggest that a share repurchase announcement may lack credibility. They reach a number of conclusions:

[This result] suggests that the market has some ability to forecast actual repurchases because inaccurate market forecasts should decrease the informativeness of actual share repurchases. Finally, it suggests that payoffs to firms that announce repurchase programs without actually having plans to repurchase any shares are minimal. Apparently the market can (at least partially) see through attempts at such manipulation. ${ }^{37}$

\footnotetext{
${ }^{36}$ Stephens and Weisbach (1998), p. 325 and p. 327.

${ }^{37}$ See idem. The term in curved parentheses is the authors' original quotation.
} 
Stephens and Weisbach (1998) conclude that investors evaluate a firm's credibility to assess the informativeness of the announcement and investors "can (at least partially) see through” less credible announcements.

Chan et al. (2003) also include actual repurchase activity subsequent to the share repurchase announcement as an independent variable in the regression of announcement abnormal returns. They find that the coefficient on actual buyback activity is not significant. However, when the measure of actual buyback activity is interacted with a high book-to-market dummy variable, they find a significant positive relationship and conclude that "while markets do not seem to react favorably to value-firms, they do seem to respond more favorably to value-firms that, ex-post, actually acquire stock.”

The theoretical problem with including the measure of ex-post actual share repurchases, as expressed by Chan et al. (2003), is that "at the time of the announcement, this [ex-post repurchase] is unknown to investors." Therefore, both Stephens and Weisbach (1998) and Chan et al. (2003) assume that investors have some degree of foresight. In this study, we modify Stephens and Weisbach’s (1998) methodology by adjusting the variable used as a proxy measure for announcement credibility.

\subsection{Measuring Credibility}

In order to test our hypothesis that market participants use past repurchase data to gauge the credibility of share repurchase announcements, a proxy for credibility must be established. But how does one measure a variable that, at first glance, seems to be qualitative in nature? If reputation is based on an agent's earlier actions, as suggested by Sobel (1985), then a proxy measure for credibility should incorporate an agent's past behavior. In the case of share repurchases, a firm's historical record of its past share repurchase programs offers quantitative data to measure a firm's past behavior. We 
construct a number of indices to proxy for the announcement credibility of a repurchasing firm based on historical data.

\subsubsection{Credibility index A}

Instead of using the ex-post measure of share repurchases as in Stephens and Weisbach (1998), our first credibility index utilizes the completion rate of the firm's most recent share repurchase program as a proxy for announcement credibility. Equation 5.1 presents the calculation for the credibility index:

$$
\text { credibility index } A_{i, 0}=\frac{\text { shares actually acquired }_{i,-1}}{\text { shares announced }{ }_{i,-1}}
$$

where credibility index $A_{i, 0}$ is the credibility index for firm $i$ for the current share repurchase announcement (period 0 ), shares actually acquired ${ }_{i,-1}$ is the number of shares actually repurchased during firm i's most recent (period -1) repurchase program, and shares announced $_{i,-1}$ is the number of shares announced to be repurchased for firm i's most recent (period -1) share repurchase program. This credibility index assigns higher announcement credibility to firms that have higher completion rates for previous repurchase programs. The value for credibility index $A$ will take a value between 0 and $1^{38}$

We believe that the lagged measure of actual share repurchases is a more appropriate proxy for announcement credibility compared to the ex post completion rate because it is based on historical information that investors have access to at the time of

\footnotetext{
${ }^{38}$ For any firm that has a completion rate greater than 100 percent, we assign that firm a credibility index $A$ value of 1 .
} 
the repurchase announcement, rather then relying on the assumption of investor foresight of possible future repurchases. At the time of a repurchase announcement, we assume that investors evaluate the likelihood that a firm will actually repurchase shares based on the firm's record of past repurchases. ${ }^{39}$

\subsubsection{Adjusted credibility index B}

Credibility index A is simple, intuitive, and easily observable, which makes it a desirable variable for a proxy measure of credibility. However, the simplicity of the variable may present some drawbacks when it is used as a proxy for announcement credibility. Specifically, the variable does not account for price movement that occurs after the share repurchase announcement. Cook et al. (2004), Ikenberry et al. (2000), and Stephens and Weisbach (1998) find that firms strategically repurchase stock in response to price movements. That is, actual share repurchases are negatively related to the firm's prior short-term excess stock return. ${ }^{40}$ Furthermore, Ikenberry et al. (2000) find a negative relationship between a firm's share repurchase completion rate and the firm's

${ }^{39}$ In concurrent research, Moore (2005) proposes to use a repurchasing firm's most recent completion rate as a proxy for announcement credibility. However, the paper is only in the proposal stage (at the time of writing) and does not present any empirical results. In addition, the author proposes to use a smaller sample period (1998-2004) and constructs his sample using an alternative source for identifying share repurchase programs (Lexis-Nexis). This study also offers an original contribution in the construction of various credibility indices to measure announcement credibility (see next section).

${ }^{40}$ Cook et al. (2004) find that a firm is more likely to repurchase shares if the prior 3-day excess return is negative. Ikenberry et al. (2000) find that the proportion of shares repurchased in a given month is negatively related to the firm's excess stock return in the prior month. Stephens and Weisbach (1998) find that quarterly share repurchases are negatively related to the prior quarter excess return of the firm. 
excess return during the share repurchase program. These findings suggest that firms tend to increase stock repurchases when prices decrease and restrain from repurchasing when prices rise.

The signaling hypothesis implies that a firm will announce a share repurchase program when management feels that the firm's stock is undervalued. ${ }^{41}$ If the firm's stock price declines after the share repurchase announcement, then the firm's equity will remain undervalued. Therefore, management will have a strong incentive to repurchase shares. However, if the stock price increases after the share repurchase announcement, management may feel that the firm's stock is no longer undervalued. As a result, management may no longer have an incentive to repurchase shares and may refrain from doing so.

Credibility index A does not account for this conditional repurchasing behavior. Suppose that we have two companies, Company U and Company D, and both companies fail to repurchase any shares in the 12 months following the share repurchase announcement (i.e. 0 percent completion rates). However, Company U’s stock price steadily increases over the 12-month period following the announcement and Company D’s stock price steadily declines over the same 12-month period. If each firm originally announced a share repurchase program in response to management's belief of undervaluation, then the two firms in our example face different incentives to repurchase shares. Company D has a strong incentive to repurchase shares because its stock is even

41 For the remainder of the paper, we refer to undervaluation and overvaluation as management's belief that a firm is undervalued or overvalued based on management's private information. 
more undervalued (as perceived by management) throughout the repurchasing period than it was at the time of the share repurchase announcement. In contrast, Company $\mathrm{U}$ may not have an incentive to repurchase any shares because its stock may no longer be undervalued (as perceived by management) during the repurchasing period. However, if we use credibility index A as a proxy for the announcement credibility of future share repurchase programs, both firms will be assigned the same credibility index value of zero. In reality, Company $\mathrm{U}$ may have repurchased shares if an optimal opportunity arose (i.e. lower stock price during repurchasing period). On the other hand, Company D had ample opportunity to repurchase shares (i.e. decreasing stock price over repurchasing period). Therefore, it may be inappropriate to assign both firms the same credibility index value.

To overcome this problem, we construct a second credibility index, credibility index $B$. If we assume that signaling undervaluation is the main motivation for a share repurchase announcement, then a firm will announce a share repurchase program when its management believes, based on their private information, that the company's stock price is undervalued in the market. Equation 5.2 states the condition when a company's stock is undervalued:

$$
P_{0} \prec \frac{\left.E_{0}\left|P_{t}\right| I_{t}^{p}\right]-C}{(1+R)}
$$

where $t$ is the number of days after the repurchase announcement, $P_{0}$ is the market price of the company's stock on the day of the announcement, $\left.E_{0}\left|P_{t}\right| I_{t}^{p}\right]$ is management's expected future value (based on their private information, $p$ ) of the firm's stock $t$ days from the time of the repurchase announcement, $C$ is the transaction costs associated with repurchasing shares (assumed to be zero), and $R$ is the firm's expected rate of return over 
the period from day 0 to day $t$. Under this assumption, a firm will have an incentive to repurchase stock on day $t$ of the repurchasing period if:

$$
P_{t} \prec P_{0}(1+R)
$$

Equation 5.3 states that a firm is undervalued (according to management) if the stock price $t$ days after the announcement of a share repurchase program is less than the stock price on the announcement date adjusted for the expected rate of return. We will refer to the right side of equation 5.3 as the adjusted stock price. Furthermore, we assume that the market model is an approximation of the firm's expected rate of return:

$$
R_{t}=\hat{\alpha}+\hat{\beta} R_{M, t}
$$

where $R_{t}$ is the firm's expected rate of return on day $t, R_{M, t}$ is the market return on day $t$, and $\hat{\alpha}$ and $\hat{\beta}$ are parameter estimates from the OLS regression of equation 4.2. Therefore, equation 5.3 becomes:

$$
P_{t} \prec P_{0} \times \prod_{k=0}^{t}\left(1+\hat{\alpha}+\hat{\beta} R_{M, k}\right)
$$

From management's perspective, a firm is undervalued $t$ days after the share repurchase announcement if equation 5.5 is satisfied. Therefore, a firm will have an incentive to repurchase shares on day $t$ if equation 5.5 is satisfied. Again, we refer to the term in the right side of equation 5.5 as the adjusted stock price. This adjusted stock price can be viewed as the stock price that management believes is the minimal fair market value of the firm. If the market price on day $t$ is lower than the adjusted stock price, then the firm is undervalued. If the market price on day $t$ is higher than the adjusted stock price, then management believes that the firm may not be undervalued. If equation 5.5 is satisfied on day t (i.e. firm is undervalued), then we classify day $t$ as an optimal trading day. 
For example, assume that the market rate of return over the repurchasing period is zero and that management's private information set remains constant. The rationale is that if management believes the stock of its firm is undervalued at the price level, $P_{0}$ (the market price at the time of the announcement), then the stock should remain undervalued from the perspective of management if the market price of the stock on day $t$ of the repurchasing period is less than $P_{0}$. Thus, in this case, day $t$ would be considered an optimal trading day. Equation 5.5 adjusts $P_{0}$ by the firm's expected rate of return, as calculated by the market model. The rationale for adjusting the firm's stock price by the expected rate of return is to account for general market movements. For example, if the market return is positive over the repurchasing period and a repurchasing firm's stock does not increase substantially, then management may feel that its stock is undervalued as a result of the stock's underperformance relative to the market-adjusted expected return.

Next, we create a binary variable, $U_{t}$, which takes the value of 1 if day $t$ of the repurchasing period is an optimal trading day (i.e. firm is undervalued) and a value of 0 if day $t$ is not an optimal trading day:

$$
U_{t}=\left\{\begin{array}{l}
0 \text { if } P_{t} \succ P_{-3} \times \prod_{k=3}^{t}\left(1+\hat{\alpha}+\hat{\beta} R_{M, k}\right) \\
1 \text { if } P_{t} \prec P_{-3} \times \prod_{k=3}^{t}\left(1+\hat{\alpha}+\hat{\beta} R_{M, k}\right)
\end{array} \text { for } 3 \leq t \leq 25042\right.
$$

42 According to TSX regulations, a firm can commence repurchasing shares two days after receiving approval from the TSX. Therefore, the share repurchasing period begins 3 days after the share repurchase announcement. We substitute $P_{0}$ with $P_{-3}$ in equation 5.6, since this is the stock price that occurs on the first day prior to the 5-day event period (days -2 to +2 ). Our results are virtually identical when the stock price on the day of the announcement $\left(\mathrm{P}_{0}\right)$ is used in replacement of the stock price that occurs prior to the event window $\left(\mathrm{P}_{-3}\right)$. 
Next, we calculate the total number of optimal trading days in the repurchasing period divided by the total number of repurchasing days in the 12-month repurchasing period:

$$
D_{i, 0}=\frac{\sum_{t=3}^{250} U_{t}}{248}
$$

where $D_{i, 0}$ measures the opportunity that firm $i$ has to repurchase shares during the repurchasing period for the current (period 0) share repurchase announcement. ${ }^{43} D_{i, 0}$ will take a value between 0 and 1.

The value for $D_{i, 0}$ can be viewed as the market's expectation of the completion rate for the repurchasing firm. For example, if $D$ is equal to 1 (i.e. the firm is undervalued on every day of the repurchasing period) then the repurchasing firm had ample opportunity to complete its share repurchase program and the market would expect a credible firm to complete its share repurchase program under such conditions. On the other hand, if $D$ is equal to 0 (i.e. the firm is not undervalued on any day of the repurchasing period) then the repurchasing firm did not have optimal conditions for repurchasing shares and the market would not expect the firm to complete its share repurchase program. We can now construct our second credibility index as follows:

\footnotetext{
${ }^{43}$ For thinly traded stocks that may not necessarily trade on every single day of the repurchasing period, the number of days in the share repurchasing period may not equal 248 days. We adjust the number of days in the repurchasing period to account for days where no transactions occur. For example, if the market did not exchange any shares for company $\mathrm{X}$ on one particular day of the repurchasing period, then the number of days in the repurchasing period would equal 247 days.
} 


$$
\text { credibility index } \begin{aligned}
B_{i, 0} & =\frac{\text { shares actually acquired }_{i,-1}}{\text { shares announced }}-D_{i,-1} \\
& =\text { credibility index } A_{i,-1}-D_{i,-1}
\end{aligned}
$$

where credibility index $B_{i, 0}$ is the credibility index for firm $i$ for the current share repurchase announcement (period 0 ), shares actually acquired ${ }_{i,-1}$ is the number of shares actually repurchased during firm i's most recent (period -1) repurchase program, shares announced $_{i,-1}$ is the number of shares announced to be repurchased for firm $i$ 's most recent (period -1) share repurchase program, and $D_{i,-1}$ is the market's expected completion rate for firm i's most recent (period -1) share repurchase program, as defined in equation 5.7. Accordingly, credibility index $B$ will take a value between -1 and +1 , where a higher value denotes greater announcement credibility.

Credibility index B is a variation of our first credibility index and it accounts for the market's expected completion rate when measuring a repurchasing firm's announcement credibility. Credibility index B is simply calculated as the firm's completion rate for its most recent share repurchase program minus the market's expected completion rate for the firm's most recent share repurchase program. In other words, a firm achieves announcement credibility by actually repurchasing shares and a firm loses announcement credibility when it fails to repurchase shares when conditions are optimal for repurchasing.

However, in order to assume that $D$ represents the market's expected completion rate for the repurchasing firm, we must make some assumptions regarding the market's assessment of the share repurchase activity of a firm. First, it is assumed that the market expects firms to repurchase shares at a constant rate. That is, for each optimal 
trading day, the market expects the repurchasing firm to repurchase a 1/248 proportion of the number of shares targeted for repurchase. Second, we assume that the market is indifferent to whether a firm repurchases shares on an optimal trading day or whether a firm repurchases shares on a non-optimal trading day. In the eyes of the market, any share repurchase increases a firm's credibility, regardless of the undervaluation status of the firm's stock price.

We now return to our example of Company D (stock price consistently decreasing during repurchasing period, or $D$ is equal to 1 ) and Company $\mathrm{U}$ (stock price consistently increasing during repurchasing period, or $D$ is equal to 0 ). Recall that both companies have 0 percent completion rates for their most recent share repurchase programs. We now find that Company D has a value for credibility index B of -1 and Company $\mathrm{U}$ has a value for credibility index B of 0 . However, for credibility index A, both companies would have an index value of 0 . Even though both companies have a previous completion rate of 0 percent, credibility index B assigns a lower credibility index value to Company D compared to Company U. The market expected Company D to repurchase shares (due to Company D's stock price consistently decreasing over the repurchasing period), but the market did not expect Company $\mathrm{U}$ to repurchase any shares (due to Company U's stock price consistently increasing over the repurchasing period). Therefore, Company D's announcement credibility is lower relative to Company U's announcement credibility.

Next, we assume that the most recent completion rates for the two companies in the above example are 100 percent. We now find that Company D has a value for credibility index B of 0 and Company $\mathrm{U}$ has a value for credibility index B of +1 . However, for credibility index A, both companies would have an index value of 1 . 
Credibility index B assigns a lower credibility index value to Company D compared to Company U. Even though both companies have a previous completion rate of 100 percent, the market did not expect Company $\mathrm{U}$ to complete its share repurchase program (due to Company U's stock price consistently increasing over the repurchasing period). Therefore, the market was "surprised" by the share repurchases conducted by Company U. On the other hand, the market expected Company D to complete its share repurchase program. As a result, Company U's announcement credibility is higher relative to Company D’s announcement credibility.

If we divide our sample of share repurchase announcements into quartiles based on the values for credibility index $A$ and credibility index $B$, we can examine the average abnormal return observed for each quartile. Table 5-1A and Table 5-1B include the average CARs for each quartile. The tables also include another category, first time announcements. Firms that announce their first repurchase program do not have a completion rate for a previous share repurchase program (because a previous share repurchase program does not exist for first time announcers). Thus, first time announcements will not have a value for credibility index A or B. Therefore, we include this group separately from the statistics for the quartiles. Table 5-1A displays a general upward trend in the average CAR from lower to higher quartiles for credibility index A. Although all average quartile CARs are significant at the 10 percent level, the lower quartiles (i.e. firms that have lower values for credibility index A) seem to have lower average CARs compared to higher quartiles (i.e. firms that have higher values for credibility index A). The first quartile has an average CAR of 0.99 percent, compared to the top quartile's average CAR of 2.33 percent. These results provide evidence in 
support of our main hypothesis that credible announcers achieve higher abnormal returns compared to less credible firms.

Table 5-2B reports similar statistics as the previous table, except the sample is divided into quartiles according to values for credibility index $B$. The results are similar to those of Table 5-1A. However, on average, the repurchase observations included in the first quartile of credibility index B (i.e. firms with the lowest announcement credibility) do not experience any significant abnormal returns on the announcement of a share repurchase program. This suggests that the market does not react to the share repurchase announcements of those firms that lack announcement credibility. The other quartiles have average CARs that are significantly greater than zero, suggesting that the market reacts favorably to share repurchase announcements of firms that have established some degree of announcement credibility.

The average CAR for first time announcements is 3.03 percent and is significant at the one percent level. The average CAR for first-time announcers is higher than any one of the quartile's average CARs. This suggests that first time repurchasers experience higher abnormal returns compared to repeat announcers. Our results are similar to Jagannathan and Stephens (2003), who report that infrequent repurchase announcements (firms that only announced one share repurchase program within the previous five years) experience a stronger positive reaction from the market compared to repeat repurchases. The authors suggest that infrequent repurchasers are more likely to be motivated by undervaluation compared to firms that regularly repurchase shares. 
Table 5-1A. Abnormal returns for each quartile of credibility index A

\begin{tabular}{ccccccccc}
\hline \multirow{2}{*}{ Quartile } & \multicolumn{3}{c}{ Credibility Index A } & & & & \\
\cline { 2 - 4 } & Mean & Min & Max & & CAR & t-stat. & p-value & N \\
\hline 1 & 0.0049 & 0.0000 & 0.0326 & & $0.99 \%$ & 2.6535 & $(0.0084)$ & 278 \\
2 & 0.1123 & 0.0326 & 0.2109 & $0.75 \%$ & 1.7336 & $(0.0841)$ & 278 \\
3 & 0.3731 & 0.2118 & 0.5799 & $1.35 \%$ & 3.0501 & $(0.0025)$ & 279 \\
4 & 0.8637 & 0.5806 & 1.0000 & $2.33 \%$ & 5.5827 & $(0.0000)$ & 278 \\
\hline $\begin{array}{c}\text { First time } \\
\text { announcements }\end{array}$ & N/A & N/A & N/A & & $3.03 \%$ & 6.2267 & $(0.0000)$ & 394 \\
\hline
\end{tabular}

The sample is divided into quartiles according to values for credibility index A. Table 5-1A presents the mean CAR (over 5-day event window) for each quartile and the mean, minimum, and maximum values for credibility index A for each quartile. A firm that announces a repurchase program for the first time will not have a previous completion rate, and thus will not have a value for credibility index A. Therefore, we group all first time announcements into one group.

Table 5-1B. Abnormal returns for each quartile of credibility index B

\begin{tabular}{ccccccccc}
\hline \multirow{2}{*}{ Quartile } & \multicolumn{3}{c}{ Credibility Index } & & & & \\
\cline { 2 - 4 } & Mean & Min & Max & CAR & t-stat. & p-value & N \\
\hline 1 & -0.7928 & -1.0000 & -0.5559 & $0.44 \%$ & 1.0344 & $(0.3019)$ & 278 \\
2 & -0.3194 & -0.5536 & -0.0747 & $1.74 \%$ & 4.2477 & $(0.0000)$ & 278 \\
3 & 0.0338 & -0.0726 & 0.1697 & $1.51 \%$ & 3.6658 & $(0.0003)$ & 279 \\
4 & 0.5326 & 0.1737 & 1.0000 & $1.73 \%$ & 3.9831 & $(0.0001)$ & 278 \\
\hline $\begin{array}{c}\text { First time } \\
\text { announcements }\end{array}$ & $\mathrm{N} / \mathrm{A}$ & $\mathrm{N} / \mathrm{A}$ & $\mathrm{N} / \mathrm{A}$ & $3.03 \%$ & 6.2267 & $(0.0000)$ & 394 \\
\hline
\end{tabular}

The sample is divided into quartiles according to values for credibility index B. Table 5-1B presents the mean CAR (over 5-day event window) for each quartile and the mean, minimum, and maximum values for credibility index B for each quartile. A firm that announces a repurchase program for the first time will not have a previous completion rate, and thus will not have a value for credibility index B. Therefore, we group all first time announcements into one group. 


\subsection{Multivariate Analysis}

To further explore the relationship that credibility may play in the cross-sectional variation of abnormal returns surrounding the announcement of a repurchase program, we perform a multivariate analysis. We utilize a number of regression equations that take the form:

$$
\text { CAR }_{i}=\beta_{0}+\beta_{1} \text { CREDIBILITY }_{i}+\sum_{2}^{j} \beta_{j} \text { CONTROL }_{i, j}+\varepsilon_{i}
$$

where $C A R$ is the cumulative abnormal return for share repurchase program $i$, CREDIBILITY is one of the credibility indices described in section 5.1 and CONTROL is a set of control variables that previous research has shown to affect the cross-sectional variation in repurchase announcement returns.

If our main hypothesis is valid, then we would expect to find a significantly positive estimate for $\beta_{1}$ in equation 5.9. That is, firms that have a reputation for completing their share repurchase programs should experience higher abnormal returns compared to firms that have a reputation for not following through with their share repurchase announcements. We also add another variable, subsequent completion rate as examined in Stephens and Weisbach (1998). This variable is the ex-post number of shares repurchased in the 12 months following the repurchase announcement. 
We use a number of control variables that are predominate in the share repurchase literature. ${ }^{44}$ The variable, $\%$ of shares announced, measures the number of shares stated to be repurchased as a percentage of total shares outstanding in the month previous to the announcement of the share repurchase program. The variable, pre-event $C A R$, is the cumulative abnormal return over the one-year period prior to the announcement date, ${ }^{45}$ size is the rank (where 1 is lowest) of the market capitalization of the announcing firm, ${ }^{46}$ beta is the estimation of the firm's beta from the market model (equation 4.2), cash is the value of the firm's cash and cash equivalents scaled by total assets in the year previous to the announcement, and book-to-market is the ratio of book-to-market equity in the year previous to the announcement ${ }^{47}$.

Table 5-2 provides descriptive statistics of the sample used in the multivariate regression. The mean value for $\%$ of shares announced is 5.79 percent (5.00 percent median), this is consistent with the maximum allowable amount of shares that can be repurchased according to the guidelines of the TSX. The mean value for the long-term

\footnotetext{
${ }^{44}$ Discussion of the rationale for inclusion and the expected parameter estimates for control variables is included in the next section, 5.3.1 Multivariate results for credibility index A.

${ }^{45}$ The variable, pre-event $C A R$, measures the cumulative abnormal return over days -3 to -252 (relative to the announcement), where the abnormal return is calculated by subtracting the CFMRC value weighted market return from the company's return.

${ }^{46}$ Size rank is calculated as the rank, relative to the rest of the sample of share repurchases, of the firm's size, calculated as the closing share price at the end of the month prior to the announcement multiplied by shares outstanding.

${ }^{47}$ Values for cash and equivalents, total assets, and book value per share are from Compustat. Market security prices are from CFMRC.
} 
pre-event $C A R$ and the short-term pre-event $C A R$ is 6.26 and -1.63 percent, respectively. ${ }^{48}$ This suggests that firms that announce share repurchase programs, on average, do not experience long-term negative price performance prior to the repurchase announcement. However, it seems that the repurchase announcement is preceded by a short-term price decline. The average beta is less than one, suggesting that the average repurchasing firm is less risky than the overall market. The mean value for cash is 11.73 percent (5.75 percent median), suggesting that announcing firms, on average, hold roughly one-tenth of the book value of their assets in cash and cash equivalents.

\footnotetext{
${ }^{48}$ The variable, pre-event CAR (long-term), measures the excess CAR over the one-year period prior to the repurchase announcement. The variable, pre-event CAR (short-term), measures the excess CAR over the 40-day period prior to the repurchase announcement. The time horizons used to measure the CAR prior to the repurchase announcement are consistent with the time horizons of previous studies.
} 
Table 5-2. Descriptive statistics for sample used in multivariate regression

\begin{tabular}{lccc}
\hline Variable & Mean & Median & $\begin{array}{c}\text { Standard } \\
\text { Deviation }\end{array}$ \\
\hline \% of shares announced & $0.0579 * *$ & 0.0500 & 0.0324 \\
pre-event CAR (long-term) & $0.0626 * *$ & 0.0529 & 0.4331 \\
pre-event CAR (short-term) & $-0.0163 * *$ & -0.0121 & 0.1807 \\
beta & $0.5314 * *$ & 0.4369 & 0.4806 \\
book-to-market & $0.7923 * *$ & 0.4719 & 1.2721 \\
cash & $0.1173 * *$ & 0.0575 & 0.1552 \\
credibility index A & $0.3388 * *$ & 0.2119 & 0.3436 \\
credibility index B & $-0.1365 * *$ & -0.0736 & 0.5119 \\
\hline
\end{tabular}

Table 5-2 provides descriptive statistics for the sample used in the regression of equation 5.9. The variable, $\%$ of share announced, measures the percent of total shares outstanding that the repurchaser announces it is repurchasing, pre-event CAR (long-term) is the prior one-year cumulative abnormal return (calculated as the firm return minus the return on the CFMRC value weighted index) over the window (-3 to -252), preevent CAR (short-term) is the cumulative abnormal return prior to the repurchase announcement (calculated as the firm return minus the return on the CFMRC value weighted index) over the 40-day window prior to the event (-3 to -42), beta is the measure of systematic risk measured by the market model coefficient estimated over the estimation window (-270 to -21), book-to-market is the firm's ratio of book to market equity in the sample, and cash is the amount of cash and equivalents scaled by total assets. ${ }^{* *}$ denotes that the mean is statistically different from zero at the one percent level, except for beta where ${ }^{* *}$ denotes that the mean value for beta is statistically different from one. 


\subsection{Results}

In this section we present the results from the multivariate regression analysis. We investigate two different indices as proxy measures for announcement credibility. Accordingly, this section presents the results for credibility index $A$ in sub-section 5.3.1 and the results for credibility index B in sub-section 5.3.2.

\subsubsection{Multivariate results for credibility index A}

Table 5-3 provides the results from the regression of equation 5.9 using our first credibility index, credibility index $A .{ }^{49}$ Table 5-3 presents three different models that analyze different combinations of explanatory variables. Previous studies (see Comment and Jarrell, 1991; Kahle, 2002; Michaely and Grullon, 2004) have found a negative relationship between the abnormal return in the pre-announcement period and the abnormal return on the announcement of the repurchase program. That is, the market reacts more favorably to share repurchase announcements for firms that experience poor price performance prior to the announcement. The results in Table 5-3 are consistent with these findings as the coefficient on pre-event $C A R$ is negative and statistically significant. In the share repurchase literature, this negative relationship is seen as evidence for the signaling/undervaluation hypothesis. Firms tend to announce repurchases when their stock price has declined and the market reacts more favorably to

\footnotetext{
${ }^{49}$ See Appendix A, Table A-1 for the correlation matrix for the variables used in Models 1 and 2 and Table A-2 for a correlation matrix for the variables used in Model 3. The announcement credibility variable, Credibility Index A, is not substantially correlated with any of the main control variables. This suggests that multicollinearity is not a major concern when interpreting our parameter estimates for announcement credibility.
} 
firms that experience poor price performance prior to the repurchase announcement. Our results are consistent with these findings.

The coefficient on the variable that measures the percentage of shares targeted for repurchase (\% of shares announced) is not significant in any of the three models. However, prior studies on U.S. repurchasing firms find a significant positive relationship between the target percent of shares announced and announcement abnormal returns (see Chan et al., 2004; Grullon and Michaely, 2002). Canadian regulations place a restriction on the maximum percent of shares outstanding that can be repurchased in a twelve month period. ${ }^{50}$ However, in the U.S. firms do not face any restrictions on the size of a share repurchase program. Grullon and Michaely (2004) and Chan et al. (2004) find that the mean share repurchase program size for U.S. firms is for 6.77 and 6.90 percent of shares outstanding, respectively (compared to the 5.79 percent mean size for Canadian repurchase programs). Furthermore, the average share repurchase program size for U.S. firms varies from year to year. This may explain why the size of the repurchase program has a significant effect on the announcement abnormal return for U.S. firms, but no apparent relationship for Canadian firms.

\footnotetext{
${ }^{50}$ The maximum allowable amount of shares that can be repurchased is the greater of 5 percent of shares outstanding or 10 percent of the public float.
} 
Table 5-3. Multivariate regression results for credibility index A

\begin{tabular}{|c|c|c|c|}
\hline Model & 1 & 2 & 3 \\
\hline Intercept & $\begin{array}{l}0.0271 \text { ** } \\
(0.0000)\end{array}$ & $\begin{array}{l}0.0165 \text { ** } \\
(0.0312)\end{array}$ & $\begin{array}{l}0.0176 \text { * } \\
(0.0388)\end{array}$ \\
\hline \multicolumn{4}{|l|}{ CONTROL Variables: } \\
\hline$\%$ of shares announced & $\begin{array}{l}0.0062 \\
(0.9220)\end{array}$ & $\begin{array}{l}0.0157 \\
(0.8299)\end{array}$ & $\begin{array}{l}0.0241 \\
(0.7401)\end{array}$ \\
\hline pre-event CAR & $\begin{array}{l}-0.0149 \text { * } \\
(0.0016)\end{array}$ & $\begin{array}{r}-0.0052 \\
(0.3778)\end{array}$ & $\begin{array}{l}-0.0136 \text { * } \\
(0.0148)\end{array}$ \\
\hline size & $\begin{array}{c}-3.01 \mathrm{E}-05 \text { ** } \\
(0.0000)\end{array}$ & $\begin{array}{c}-2.19 \mathrm{E}-05 \text { ** } \\
(0.0005)\end{array}$ & $\begin{array}{c}-2.65 \mathrm{E}-05 \text { * } \\
(0.0000)\end{array}$ \\
\hline beta & $\begin{array}{l}0.0112 \\
(0.0126)\end{array}$ & $\begin{array}{l}0.0087 \\
(0.1148)\end{array}$ & $\begin{array}{l}0.0090 * \\
(0.0868)\end{array}$ \\
\hline book-to-market & & & $\begin{array}{l}0.0027 \\
(0.1690)\end{array}$ \\
\hline cash & & & $\begin{array}{l}0.0447 \\
(0.0044)\end{array}$ \\
\hline \multicolumn{4}{|l|}{ CREDIBILITY Variables: } \\
\hline credibility index A & $\begin{array}{l}0.0149 \text { * } \\
(0.0117)\end{array}$ & $\begin{array}{l}0.0176 \text { ** } \\
(0.0275)\end{array}$ & $\begin{array}{l}0.0131 \text { ** } \\
(0.0476)\end{array}$ \\
\hline credibility index A (-2) & & $\begin{array}{r}-0.0066 \\
(0.4441)\end{array}$ & \\
\hline credibility index A (-3) & & $\begin{array}{l}0.0019 \\
(0.7944)\end{array}$ & \\
\hline $\mathrm{n}$ & 1112 & 554 & 769 \\
\hline adjusted $R^{2}$ & 0.0423 & 0.0210 & 0.0597 \\
\hline F-test & $10.8227^{* *}$ & $2.6955^{\star *}$ & 7.9656 ** \\
\hline
\end{tabular}

Table 5-3 reports cross-sectional regression results of the initial market reaction to the share repurchase announcement. The dependent variable is the cumulative abnormal return calculated using the market model for the 5-day event window $(-2,+2)$ surrounding the announcement date. The explanatory variables are as follows: \% of share announced is the percent of total shares outstanding that the repurchaser announces it is repurchasing, pre-event CAR is the cumulative abnormal return (calculated as the firm return minus the return on the CFMRC value weighted index) over the one-year period prior to the event window ( -3 to -252$)$, size is the rank of the firm's market capitalization in the sample, beta is the measure of systematic risk measured by the market model coefficient estimated over the estimation window (-270 to -21), book-to-market is the firm's ratio of book to market equity, cash is the amount of cash and short term investments scaled by total assets, credibility index $A$ is the firm's most recent share repurchase completion rate (calculated as the number of shares actually acquired divided by the target number of shares), credibility index A (-2) is the completion rate for the firm's second most recent share repurchase program, and credibility index $A(-3)$ is the completion rate for the firm's third most recent share repurchase program. The numbers in parentheses are $p$-values. ${ }^{* *}$ and ${ }^{*}$ denote significance at the 1 percent and 5 percent levels, respectively. A $p$-value of (0.0000) denotes that the $p$-value is less than 0.001 . We also include the test statistic for the F-test that tests the null hypothesis that all parameter estimates are simultaneously equal to zero. 
Previous studies have found a negative relationship between firm size and announcement abnormal returns (see Chan et al., 2004; Kahle, 2002; Michaely and Grullon, 2004). Researchers' rationale for this relationship is that firm size acts as a proxy for informational asymmetries between the market and firm insiders. Larger firms tend to be closely scrutinized by the media, institutional investors, and financial analysts, leading to less information asymmetries. Therefore, a share repurchase announcement may be more informative to investors of small firms than for investors of larger firms. Consistent with previous research, Table 5-3 reports that the parameter estimate for size rank is negative (larger firms experience less abnormal return, ceteris paribus) and statistically significant. We also include a measure of systematic risk in our regressions in Table 5-3 (see McNally, 1999). The coefficient is significantly positive, suggesting that firms whose stock returns are more sensitive to the market return experience greater abnormal announcement returns.

The last set of control variables that we include in the multi-variant analysis are variables to control for cash and book-to-market values, which are included in Model 3 of Table 5-3. Some studies have found a positive, albeit weak (i.e. low significance level) relationship between book-to-market values and announcement abnormal returns (see Michaely and Grullon, 2004; Li and McNally, 2007). Researchers interpret this result as evidence for the signaling hypothesis, since low book-to-market firms may be more susceptible to undervaluation. The sign for the coefficient of book-to-market equity for our regression is positive, as expected. However, we find that the parameter estimate for book-to-market is not significant ( $p$-value of 16.9 percent). Previous studies have also found a positive relationship between announcement abnormal returns and the amount of cash on the firm's balance sheet (see Chan et al., 2004; Kahle, 2002; Michaely and 
Grullon, 2004). This positive relationship is interpreted as evidence for the free cashflow hypothesis. Our results also indicate a significant, positive relationship between cash and announcement abnormal returns, thus providing evidence in support of the free cash-flow hypothesis. .

Our main test variable in Table 5-3 is the proxy for announcement credibility, credibility index $A$, which measures the completion rate of the firm's most recent share repurchase program. The coefficient on credibility index A is significantly positive and is robust across all three models in Table 5-3. ${ }^{51}$ The coefficient estimate in Model 1 is 0.0149 ( $p$-value of 0.0117$){ }^{52}$ In Model 3 of Table 5-3, we add two additional control variables, book-to-market and cash. The parameter estimate for credibility index A in Model 3 remains positive and significant after adding the two additional explanatory variables. $^{53}$ Therefore, our results are robust to the inclusion of these additional explanatory variables.

In general, our results from the regressions in Table 5-3 indicate that announcement abnormal returns are higher for firms that have completed a greater

\footnotetext{
${ }^{51}$ For robustness check, we perform the identical regression analysis for abnormal returns calculated using a variety of event study methodologies. The results are robust to those presented in the main body of the paper. Please refer to Section 5.4 - Robustness Tests for a detailed explanation of alternative tests for robustness.

${ }^{52}$ The $p$-value is for the test of the null hypothesis that the parameter estimate is equal to zero.

53 Our sample size is smaller in Model 1 compared to Model 3 due to the limited coverage of Canadian firms in Compustat. Compustat does not include the required data needed to construct the variables book-to-market and cash for 343 share repurchase observations in our sample.
} 
proportion of their previous share repurchase programs. The results provide evidence in support for our main hypothesis. That is, our results suggest that credible firms experience higher abnormal returns upon the announcement of a share repurchase program compared to firms that lack credibility.

The adjusted R-square values for the regressions vary depending on the regression model and range from a low of 2 percent to a high of nearly 6 percent. Although the adjusted R-square values for the regressions are relatively low, they are consistent with R-square values from prior research (see Michaely and Grullon, 2004; Kahle, 2002; Stephens and Weisbach, 1998). Furthermore, the test statistic is significant in all regression models for the F-test of the null hypothesis that all parameter estimates are simultaneously equal to zero.

In order to examine the possibility that investors evaluate the credibility of a firm's repurchase announcement based on an extended history of the firm's repurchase programs, we add two additional variables: credibility index A (-2) and credibility index A (-3). ${ }^{54}$ These variables represent the completion rates of the second and third most recent share repurchase programs, respectively. The results are presented in Model 2 of Table 5-3. The coefficients on credibility index A (-2) and credibility index A (-3) are both insignificant. However, the coefficient on our main announcement credibility variable, credibility index A, remains significantly positive. This suggests that investors

\footnotetext{
${ }^{54}$ The (-2) term in the variable, credibility index $A(-2)$, denotes the second most recent share repurchase program and the $(-3)$ term in the variable, credibility index $A(-3)$, denotes the third most recent share repurchase program.
} 
place more importance on the most recent share repurchase program when evaluating announcement credibility.

Stephens and Weisbach (1998) find a positive relationship between abnormal return and ex-post completion rates. ${ }^{55}$ Their explanation for this result is that the market may have some ability in forecasting the actual amount of ex post repurchases and can identify, to some degree, firms that do not intend to fulfill their announced share repurchase programs. In Table 5-4, we include the ex-post completion rate, denoted as subsequent completion rate $(+1)$, in the regression equations. In Models 1 and 2 , the coefficient for the ex post completion rate is significantly positive. These results are similar to the results of Stephens and Weisbach (1998). However, when we add our proxy measure of credibility, credibility index $A$, in Models 3 and 4, we find that the parameter estimates for subsequent completion rate $(+1)$ are not significantly different from zero. Furthermore, the parameter estimate for credibility index A remains significantly positive in Model 3 and is marginally insignificant in Model 4 ( $p$-value of 0.1103). This provides evidence that the most recent completion rate, credibility index $A$ (which is actually known at the time of the repurchase announcement), is more relevant to the market than the ex-post measure of actual repurchases (which is unknown at the time of the announcement) when evaluating announcement credibility.

55 Stephens and Weisbach (1998) calculate completion rates using the actual share repurchases over the two and three year periods following the share repurchase announcement. Their regression results are similar for completion rates calculated using the actual share repurchases over the one year following the repurchase announcement. 
Table 5-4. Multivariate regression results for credibility index A (with inclusion of subsequent completion rate (+1) variable)

\begin{tabular}{|c|c|c|c|c|}
\hline Model & 1 & 2 & 3 & 4 \\
\hline Intercept & $\begin{array}{l}0.0302 \text { ** } \\
(0.0000)\end{array}$ & $\begin{array}{l}0.0205 \text { ** } \\
(0.0218)\end{array}$ & $\begin{array}{l}0.0268 \text { ** } \\
(0.0000)\end{array}$ & $\begin{array}{l}0.0181 \text { ** } \\
(0.0453)\end{array}$ \\
\hline \multicolumn{5}{|l|}{ CONTROL Variables: } \\
\hline$\%$ of shares announced & $\begin{array}{l}0.0199 \\
(0.7624)\end{array}$ & $\begin{array}{l}0.0344 \\
(0.6518)\end{array}$ & $\begin{array}{l}0.0117 \\
(0.8595)\end{array}$ & $\begin{array}{l}0.0277 \\
(0.7164)\end{array}$ \\
\hline pre-event CAR & $\begin{array}{l}-0.0122 \text { ** } \\
(0.0173)\end{array}$ & $\begin{array}{l}-0.0101 * \\
(0.0994)\end{array}$ & $\begin{array}{l}-0.0121 \text { * } \\
(0.0178)\end{array}$ & $\begin{array}{r}-0.0096 \\
(0.1196)\end{array}$ \\
\hline size & $\begin{array}{c}-3.07 E-05 \text { ** } \\
(0.0000)\end{array}$ & $\begin{array}{c}-2.76 \mathrm{E}-05 \text { ** } \\
(0.0001)\end{array}$ & $\begin{array}{c}-3.05 E-05 \text { ** } \\
(0.0000)\end{array}$ & $\begin{array}{c}-2.77 \mathrm{E}-05 \text { ** } \\
(0.0001)\end{array}$ \\
\hline beta & $\begin{array}{l}0.0082 \text { * } \\
(0.0970)\end{array}$ & $\begin{array}{l}0.0052 \\
(0.3708)\end{array}$ & $\begin{array}{l}0.0091 \text { * } \\
(0.0647)\end{array}$ & $\begin{array}{l}0.0061 \\
(0.2971)\end{array}$ \\
\hline book-to-market & & $\begin{array}{r}2.52 \mathrm{E}-03 \\
(0.2175)\end{array}$ & & $\begin{array}{r}2.25 E-03 \\
(0.2701)\end{array}$ \\
\hline cash & & $\begin{array}{l}0.0455 \text { ** } \\
(0.0093)\end{array}$ & & $\begin{array}{l}0.0436 \text { ** } \\
(0.0128)\end{array}$ \\
\hline \multicolumn{5}{|l|}{ CREDIBILITY Variables: } \\
\hline credibility index A & & & $\begin{array}{l}0.0154 \text { ** } \\
(0.0296)\end{array}$ & $\begin{array}{l}0.0128 \\
(0.1103)\end{array}$ \\
\hline subsequent completion rate $(+1)$ & $\begin{array}{l}0.0114 \text { * } \\
(0.0884)\end{array}$ & $\begin{array}{l}0.0146 * \\
(0.0530)\end{array}$ & $\begin{array}{l}0.0045 \\
(0.5384)\end{array}$ & $\begin{array}{l}0.0088 \\
(0.2939)\end{array}$ \\
\hline $\mathrm{n}$ & 1000 & 677 & 1000 & 677 \\
\hline adjusted $\mathrm{R}^{2}$ & 0.0358 & 0.0528 & 0.0394 & 0.0550 \\
\hline F-test & 8.4136 ** & $6.3837 * \star$ & 7.8286 ** & 5.5774 ** \\
\hline
\end{tabular}

Table 5-4 reports cross-sectional regression results of the initial market reaction to the share repurchase announcement and includes the ex post completion rate as an independent variable. The dependent variable is the cumulative abnormal return calculated using the market model for the 5-day event window $(-2,+2)$ surrounding the announcement date. The explanatory variables are as follows: \% of share announced is the percent of total shares outstanding that the repurchaser announces it is repurchasing, pre-event CAR is the cumulative abnormal return (calculated as the firm return minus the return on the CFMRC value weighted index) over the one-year period prior to the event window (-3 to -252), size is the rank of the firm's market capitalization in the sample, beta is the measure of systematic risk measured by the market model coefficient estimated over the estimation window (-270 to -21), book-to-market is the firm's ratio of book to market equity, cash is the amount of cash and short term investments scaled by total assets, credibility index $A$ is the firm's most recent share repurchase completion rate (calculated as the number of shares actually acquired divided by the target number of shares), and subsequent completion rate $(+1)$ is the completion rate of the current repurchase program over the 12-month period following the announcement. The numbers in parentheses are $p$-values. ${ }^{* *}$ and $*$ denote significance at the 1 percent and 5 percent levels, respectively. A $p$-value of (0.0000) denotes that the $p$-value is less than 0.001 . Note that the number of observations is different from the regressions in Table 5-3 because share repurchase announcements that occur in 2005 do not have values for the ex post completion rate because, at the time of writing, share repurchase programs initiated in 2005 have not yet been completed. We also include the test statistic for the F-test that tests the null hypothesis that all parameter estimates are simultaneously equal to zero. 


\subsubsection{Multivariate results for credibility index B}

Recall that credibility index B is calculated as the firm's completion rate for its most recent share repurchase program minus the market's expected completion rate for the firm's most recent share repurchase program. The index is calculated according to equation 5.8. Credibility index B accounts for the interdependence between the level of share prices during the repurchasing period and share repurchase activity. However, credibility index A assigns the same index value to firms that have identical repurchase completion rates, regardless of the circumstances the firm faces in the repurchasing period. In this section, we examine the results for our second credibility index.

Table 5-5 presents the results of the regressions that include credibility index B as an explanatory variable. ${ }^{56}$ The parameter estimates for the control variables are very similar to the regressions in Table 5-3 that use credibility index A as the regressor and all estimates for control variables are consistent with a priori expectations and the extant literature, as described in section 5.3.1. In Model 1 of Table 5-5, the parameter estimate for credibility index B is 0.0101 ( $p$-value of 0.0123 ). In Model 2, we add the control variables, book-to-market and cash to the regressions. The parameter estimate for credibility index B remains virtually unchanged in Model 2, with a coefficient of 0.0112 (p-value of 0.0149).

\footnotetext{
${ }^{56}$ See Appendix A, Table A-3 for the correlation matrix for the variables used in Model 1 and Table A-4 for a correlation matrix for the variables used in Model 2. The announcement credibility variable, Credibility Index B, is not substantially correlated with any of the main control variables. This suggests that multicollinearity is not a major concern when interpreting our parameter estimates for announcement credibility.
} 
Our results suggest that, after accounting for the price conditions a repurchasing firm encounters during the course of its share repurchase program, firms that have a higher credibility index value experience a greater abnormal return on the announcement of a share repurchase program. These results provide further support for the main hypothesis of this thesis which states that credible firms should experience higher abnormal returns upon the announcement of a share repurchase program compared to firms that lack credibility. 
Table 5-5. Multivariate regression results for credibility index B

\begin{tabular}{lll}
\hline Model & \multicolumn{1}{c}{1} & \multicolumn{1}{c}{2} \\
\hline Intercept & $0.0331^{* *}$ & $0.0231^{* *}$ \\
& $(0.0000)$ & $(0.0060)$
\end{tabular}

CONTROL Variables:

$\%$ of shares announced

$0.0069 \quad 0.0251$

$(0.9129) \quad(0.7290)$

pre-event CAR

-0.0173 ** -0.0166 **

size

$-2.92 \mathrm{E}-05 * * \quad-2.55 \mathrm{E}-05$ **

$(0.0000) \quad(0.0001)$

beta

0.0108 ** $\quad 0.0086$

$(0.0160) \quad(0.1020)$

book-to-market

0.0027

$(0.1640)$

cash

0.0456 **

$(0.0036)$

CREDIBILITY Variables:

credibility index $B$

\begin{tabular}{cc}
0.0101 ** & 0.0112 ** \\
$(0.0123)$ & $(0.0149)$ \\
1112 & 769 \\
0.0422 & 0.0622 \\
10.8015 ** & 8.2812 ** \\
\hline
\end{tabular}

Table 5-5 reports cross-sectional regression results of the initial market reaction to the share repurchase announcement. The dependent variable is the cumulative abnormal return calculated using the market model for the 5-day event window $(-2,+2)$ surrounding the announcement date. The explanatory variables are as follows: \% of share announced is the percent of total shares outstanding that the repurchaser announces it is repurchasing, pre-event CAR is cumulative abnormal return (calculated as the firm return minus the return on the CFMRC value weighted index) over the one-year period prior to the event window ( -3 to -252), size is the rank of the firm's market capitalization, beta is the measure of systematic risk measured by the market model coefficient estimated over the estimation window (-270 to -21), book-tomarket is the firm's ratio of book to market equity, cash is the amount of cash and short term investments scaled by total assets, and credibility index $B$ is calculated as the firms most recent share repurchase completion rate minus the market's expected completion rate (see equation 5.8). The numbers in parentheses are $p$-values. ${ }^{* *}$ and ${ }^{*}$ denote significance at the 1 percent and 5 percent levels, respectively. A $p$-value of (0.0000) denotes that the $p$-value is less than 0.001 . We also include the test statistic for the F-test that tests the null hypothesis that all parameter estimates are simultaneously equal to zero. 


\subsection{Robustness Tests}

To test the robustness of our results, we calculate the abnormal return on the announcement of the share repurchase program using different event study methodologies. Table B-1 of Appendix B provides a summary of the different methodologies used in the robustness tests and the sample average CAR that results from the application of each methodology. The average CAR for the entire sample of share repurchases ranges from $1.51 \%$ to $1.92 \%$, depending on the methodology used. For the sake of brevity, we do not include the results for the multivariate analysis using the CAR from the alternative event-study methodologies. ${ }^{57}$ Overall, the results from the previous regressions in Section 5.3 are robust to alternative event-study methodologies and we observe a consistent positive relationship between announcement abnormal returns and announcement credibility measures.

To further test the robustness of our results, we construct additional credibility indices as alternative proxy measures for announcement credibility. In total, we construct five alternative credibility indices. A description of the construction of each alternative credibility index is provided in Appendix C. The alternative credibility indices, previous repurchase dummy (credibility index A2) and previous repurchase >median dummy (credibility index A3) are both variations of credibility index A. The last three alternative credibility indices are variations of credibility index B: credibility index B2, credibility index B3, and credibility index B4. The only difference between credibility index B and credibility index B2 and B3, is the definition of an optimal share repurchasing trading day

\footnotetext{
${ }^{57}$ Results are available upon request.
} 
(i.e. the condition that classifies a repurchasing firm as undervalued in the repurchasing period).

The first variation of credibility index A is the index, previous repurchase dummy, which is a dummy variable that takes the value of one if the firm repurchased any shares in its previous repurchase program (i.e. credibility index $A>0$ ). The second variation of credibility index A is the index, previous repurchase >median dummy, which is a dummy variable that takes the value of one if the firm's previous share repurchase program completion rate was greater than the overall sample median completion rate (18.30 percent).

For the sake of brevity, the results for the multivariate analysis using previous repurchase dummy and previous repurchase >median dummy as credibility indices are included in Table C- 1 of Appendix C. The results are moderately supportive of our first hypothesis, however the parameter estimates for the credibility variables are not significant in all of the regressions (only Model 3 of Table C-1 is significant). This suggests that a binary representation of a firm's announcement credibility is not as strong of a predictor of abnormal returns as a continuous variable (e.g. credibility index A).

Table C-2 reports the results for the regression equations that use the three variations of credibility index B. The parameter estimates are significantly positive for all three variations of credibility index B. Therefore, this provides further verification that the results in the previous sections are robust to different proxies for announcement credibility. The results from the robustness tests provide further evidence in support of our main hypothesis that credible announcers experience higher abnormal returns on the announcement of a share repurchase program compared to firms that lack credibility. 


\section{CHAPTER 6 \\ CONCLUSION}

\subsection{Concluding Remarks}

The extant literature reports a positive price reaction for firms announcing an open-market share repurchase program. However, these studies overlook the fact that firms that announce share repurchase programs are not obligated to follow through in the actual acquisition of their shares. This study reports that the majority of firms fail to repurchase the target amount of shares in the months following the repurchase announcement. Furthermore, many firms fail to repurchase any shares at all. Therefore, the announcement of a share repurchase program has a degree of uncertainty regarding the announcing firm's credibility. Firms that fail to complete repurchase programs are likely to be perceived as less committed to future share repurchase programs.

Literature on share repurchases suggests credibility may be an alternative explanation for the abnormal return observed on the announcement of a repurchase program (Oded, 2004; Chen et al., 2004). However, no previous evidence exists on the effect of credibility on share repurchase announcement abnormal returns. One exception is Stephens and Weisbach (1998), who examine the relationship between ex-post share repurchase completion rates and announcement abnormal returns.

This study expands on Stephen and Weisbach’s (1998) research and examines the possibility that market participants evaluate the credibility of a firm's share repurchase announcement by using information of a firm's past share repurchase history. Our research is groundbreaking in investigating the measurement and the impact of 
announcement credibility. We also offer an original contribution in the construction of a credibility index that accounts for the interdependence of share repurchases and stock price movements subsequent to the repurchase announcement.

We study the detailed information of the completion rates of share repurchase programs for firms listed on the TSX. Our results indicate a positive relationship between a firm's prior share repurchase completion rate and the abnormal return on subsequent share repurchase announcements. Therefore, we conclude that this study finds convincing evidence that investors react more favorably to the share repurchase announcements of “credible” firms compared to firms that lack credibility.

Our research is especially relevant to U.S. market regulators in determining the future market regulation regarding open-market share repurchase programs. Fried (2005) recommends that the SEC require firms to disclose specific details of open-market share repurchases prior to the repurchase transaction. For example, a firm that intends to repurchase shares in the near future must announce the instructions it provides to its broker (e.g. buy 250,000 shares at or below $\$ 25$ per share over the next five trading days) prior to the actual repurchase transaction. This type of regulation would increase market transparency and establish greater credibility of share repurchase announcements by ensuring that firm's actually follow through with their announced intentions.

\subsection{Limitations}

The indices used to quantify announcement credibility are proxy measures based on a firm's share repurchase history. There may be other unidentified factors that affect the credibility of a firm's announcement. Furthermore, Canadian regulations place size restrictions (maximum of 5 percent of shares outstanding) and time limits (12-month maximum) on share repurchase programs. Therefore, it is possible that a firm may intend 
to implement a share repurchase that is larger than the maximum allowable restriction over a period longer than the twelve month allowable duration by implementing a series of consecutive repurchases programs. However, this study considers every individual share repurchase program to be independent of previous repurchase programs. In addition, if a firm announces a share repurchase program on a regular basis, the market may develop expectations of the share repurchase announcement and the price response to the announcement may be minimal.

\subsection{Future Research}

It is possible that corporate governance issues have an effect on the credibility of an announcing firm. Therefore, it may be productive to investigate any plausible relationship between corporate governance and share repurchase announcement credibility. In addition, recent corporate events and legislation has focused on increasing the accountability of management and the credibility of financial reporting. Perhaps this shift towards improved corporate integrity has affected the share repurchase decisions of firms.

Share repurchases may have an impact on the stock's return volatility and skewness. If a firm repurchases shares in an attempt to dampen sell-side pressure, then it is possible that the firm's share repurchases create a temporary price floor. Therefore, a share repurchase transactions may lower return volatility and lower the probability of a

decrease in the firm's stock price (compared to a scenario where the firm does not actively repurchase shares). This, in turn, may influence volatility related securities, such the prices of options for the firm's stock.

In our analysis, we observed that firms with dual class share structures tend to repurchase a greater proportion of restricted voting shares compared to superior voting 
shares. Perhaps this observation represents a control issue. Further investigation may clarify this issue.

Lastly, we leave for further research the study of the effect of announcement credibility on other corporate events where, as in share repurchases, the actual implementation of the announcement is uncertain and conditional on management's discretion. 


\section{REFERENCES}

Asquith, Paul, and David W. Mullins, Jr., 1986, Signaling with dividends, stock repurchases, and equity issues, Financial Management 15, 27-44.

Baker, H. Kent, Tarun K. Mukherjee, and Gary E. Powell, 2005, Distributing excess cash: the role of specially designated dividends, Financial Services Review 14, 111-131.

Baker, H. Kent, Gary E. Powell, and E. Theodore Veit, 2003, Why companies use openmarket repurchases: a managerial perspective, The Quarterly Review of Economics and Finance 43, 483-504.

Barclay, Michael J., and Clifford W. Smith, Jr., 1988, Corporate payout policy: cash dividends versus open-market repurchases, Journal of Financial Economics 22, 61-82.

Bens, Daniel A., Venky Nagar, Douglas J. Skinner, and M.H. Franco Wong, 2003, Employee stock options, EPS dilution, and stock repurchases, Journal of Accounting and Economics 36, 51-90.

Brav, Alon, John R. Graham, Campbell R. Harvey, and Roni Michaely, 2005, Payout policy in the $21^{\text {st }}$ century, Journal of Financial Economics 77, 483-527.

Brockman, Paul, and Dennis Y. Chung, 2001, Managerial timing and corporate liquidity: evidence from actual share repurchases, Journal of Financial Economics 61, 417448.

Brown, Stephen J., and Jerold B. Warner, 1985, Using daily stock returns: the case of event studies, Journal of Financial Economics 14, 3-31.

Chan, Konan, David Ikenberry, and Inmoo Lee, 2004, Economic sources of gain in stock repurchases, Journal of Financial and Quantitative Analysis 39, 461-480.

Comment, Robert, and Gregg A. Jarrell, 1991, The relative signaling power of Dutchauction and fixed-price self-tender offers and open-market share repurchases, Journal of Finance 46, 1243-1271.

Cook, Douglas O., Laurie Krigman, and J. Chris Leach, 2003, An analysis of SEC guidelines for executing open market repurchases, The Journal of Business 76, 289-315.

Cook, Douglas O., Laurie Krigman, and J. Chris Leach, 2004, On the Timing and Execution of Open Market Repurchases, The Review of Financial Studies 17, 463498. 
Dann, Larry Y., 1981, Common stock repurchases: an analysis of returns to bondholders and stockholders, Journal of Financial Economics 9, 113-138.

DeJong, Douglas V., Robert Forsythe, Russell J. Lundholm, and Wilfred C. Uecker, 1985, A laboratory investigation of the moral hazard problem in an agency relationship, Journal of Accounting Research 23, 81-120.

Fried, Jesse M., 2005, Informed trading and false signaling with open market repurchases, California Law Review 93, 1326-1386.

Grullon, Gustavo, and Roni Michaely, 2002, Dividends, share repurchases, and the substitution hypothesis, Journal of Finance 57, 1649-1684.

Grullon, Gustavo, and Roni Michaely, 2004, The information content of share repurchase programs, Journal of Finance 59, 651-680.

Hribar, Paul, Nicole Thorne Jenkins, and W. Bruce Johnson, 2004, Stock Repurchases as an Earnings Management Device, Journal of Accounting and Economics, Forthcoming.

Ikenberry, David L., and Theo Vermaelen, 1996, The option to repurchase stock, Financial Management 25, 9-24.

Ikenberry, David, Josef Lakonishok, and Theo Vermaelen, 1995, Market underreaction to open market share repurchases, Journal of Financial Economics 39, 181-208.

Ikenberry, David, Josef Lakonishok, and Theo Vermaelen, 2000, Stock repurchases in Canada: performance and strategic trading, Journal of Finance 55, 2373-2397.

Isagawa, Nobuyuki, 2000, Open-market stock repurchase and stock price behavior when management values real investment, The Financial Review 35, 95-108.

Jagannathan, Murali, Clifford P. Stephens, and Michael S. Weisbach, 2000, Financial flexibility and the choice between dividends and stock repurchases, Journal of Financial Economics 57, 355-384.

Jagannathan, Murali, Clifford Stephens, 2003, Motives for multiple open-market repurchase programs, Financial Management 32, 71-91.

Jensen, M. C., 1986, Agency costs of free cash flow, corporate finance, and takeovers, American Economic Review 76, 323-329.

Kahle, Kathleen M., 2002, When a buyback isn't a buyback: open market repurchases and employee options, Journal of Financial Economics 63, 235-261. 
Kim, Jaemin, Nikhil Varaiya, and Ralf Schremper, 2004, Survey on open market repurchase regulations: cross-country examination of the ten largest stock markets, Working paper, San Diego State University.

Kracher, Beverly, and Robert R. Johnson, 1997, Repurchase announcements, lies and false signals, Journal of Business Ethics 16, 1677-1685.

Li, Kai, and William McNally, 2004, Open market versus tender offer share repurchases: a conditional event study, Working paper, University of British Columbia.

Li, Kai, and William McNally, 2007, The information content of Canadian open market repurchase announcements, Managerial Finance 33, forthcoming.

McNally, William J., 1999, Open market stock repurchase signaling, Financial Management 28, 55-67.

McNally, William J., 2002, Open market share repurchases in Canada, Canadian Investment Review 15, 24-31.

McNally, William J., Brian F. Smith, and Thomas Barnes, 2006, The price impacts of open market repurchase trades, Journal of Business Finance \& Accounting, forthcoming.

Miller, Merton H., and Franco Modigliani, 1961, Dividend policy, growth, and the valuation of shares, Journal of Business 34, 411-433.

Molho, Ian, 1997, The Economics of Information: Lying and Cheating in Markets and Organizations, Blackwell Publishers, Oxford.

Moore, James M., 2005, Stock repurchases in Canada: the effect of history and disclosure, Working paper, University of Waterloo.

Oded, Jacob, 2005, Why do firms announce open-market repurchase programs?, The Review of Financial Studies 18, 271-300.

Patell, James M., 1976, Corporate forecasts of earnings per share and stock price behavior: empirical test, Journal of Accounting Research 14, 246-276.

Shapiro, Carl, 1983, Premiums for high quality products as returns to reputations, The Quarterly Journal of Economics 98, 659-680.

Sobel, Joel, 1985, A theory of credibility, The Review of Economic Studies 52, 557-573.

Stephens, Clifford P., and Michael S. Weisbach, 1998, Actual share reacquisitions in open-market repurchase programs, Journal of Finance 53, 313-333. 
Stewart, Samual S., Jr., 1976, Should a corporation repurchase its own stock?, Journal of Finance 31, 911-921.

Vermaelen, Theo, 1981, Common stock repurchases and market signaling: an empirical study, Journal of Financial Economics 9, 139-183. 


\section{APPENDIX A \\ CORRELATION MATRICES FOR TABLE 5-2}

Table A-1. Correlation matrix for Table 5-3, Models 1 and 2

\begin{tabular}{|c|c|c|c|c|c|c|c|c|}
\hline & 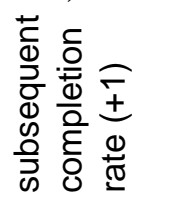 & 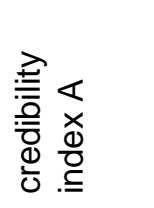 & 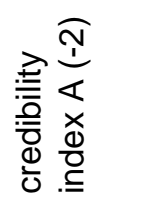 & 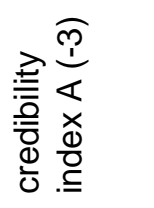 & 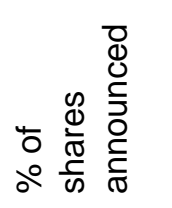 & 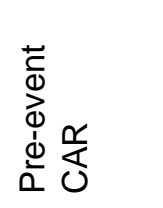 & $\frac{\mathbb{N}}{\infty}$ & $\frac{\pi}{\mathbb{0}}$ \\
\hline subsequent completion rate $(+1)$ & 1.0000 & & & & & & & \\
\hline credibility index A & $\begin{array}{l}0.4218 \\
(<.0001)\end{array}$ & 1.0000 & & & & & & \\
\hline credibility index A (-2) & $\begin{array}{l}0.3191 \\
(<.0001)\end{array}$ & $\begin{array}{l}0.4573 \\
(<.0001)\end{array}$ & 1.0000 & & & & & \\
\hline credibility index A (-3) & $\begin{array}{l}0.2306 \\
(<.0001)\end{array}$ & $\begin{array}{l}0.3086 \\
(<.0001)\end{array}$ & $\begin{array}{l}0.4274 \\
(<.0001)\end{array}$ & 1.0000 & & & & \\
\hline$\%$ of shares announced & $\begin{array}{l}0.0098 \\
(0.7564)\end{array}$ & $\begin{array}{l}0.0490 \\
(0.1027)\end{array}$ & $\begin{array}{l}0.1073 \\
(0.0026)\end{array}$ & $\begin{array}{l}0.0626 \\
(0.1413)\end{array}$ & 1.0000 & & & \\
\hline pre-event CAR & $\begin{array}{r}-0.0485 \\
(0.1253)\end{array}$ & $\begin{array}{r}-0.0007 \\
(0.9815)\end{array}$ & $\begin{array}{l}0.1571 \\
(<.0001)\end{array}$ & $\begin{array}{l}0.0957 \\
(0.0243)\end{array}$ & $\begin{array}{l}0.0428 \\
(0.1538)\end{array}$ & 1.0000 & & \\
\hline size & $\begin{array}{l}0.0352 \\
(0.2661)\end{array}$ & $\begin{array}{r}-0.0082 \\
(0.7847)\end{array}$ & $\begin{array}{r}-0.0168 \\
(0.6380)\end{array}$ & $\begin{array}{r}-0.0139 \\
(0.7439)\end{array}$ & $\begin{array}{r}-0.0509 \\
(0.0900)\end{array}$ & $\begin{array}{r}-0.0325 \\
(0.2785)\end{array}$ & 1.0000 & \\
\hline beta & $\begin{array}{l}0.0585 \\
(0.0646)\end{array}$ & $\begin{array}{r}-0.0365 \\
(0.2243)\end{array}$ & $\begin{array}{r}-0.0010 \\
(0.9782)\end{array}$ & $\begin{array}{r}-0.0084 \\
(0.8431)\end{array}$ & $\begin{array}{l}0.0434 \\
(0.1477)\end{array}$ & $\begin{array}{r}-0.1020 \\
(0.0007)\end{array}$ & $\begin{array}{l}0.3110 \\
(<.0001)\end{array}$ & 1.0000 \\
\hline
\end{tabular}


Table A-2. Correlation matrix for Table 5-3, Model 3*

\begin{tabular}{|c|c|c|c|c|c|c|c|}
\hline & 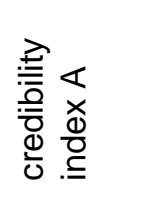 & 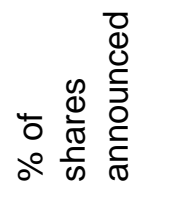 & 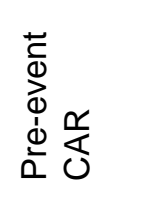 & $\frac{N}{\omega}$ & $\frac{\frac{\pi}{0}}{2}$ & 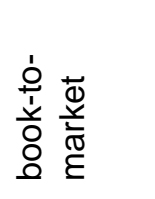 & $\begin{array}{l}\frac{1}{9} \\
\mathbb{0} \\
0\end{array}$ \\
\hline credibility index $\mathrm{A}$ & 1.0000 & & & & & & \\
\hline$\%$ of shares announced & $\begin{array}{l}0.0445 \\
(0.2178)\end{array}$ & 1.0000 & & & & & \\
\hline pre-event CAR & $\begin{array}{r}-0.0359 \\
(0.3201)\end{array}$ & $\begin{array}{l}0.0430 \\
(0.2341)\end{array}$ & 1.0000 & & & & \\
\hline size & $\begin{array}{r}-0.0146 \\
(0.6864)\end{array}$ & $\begin{array}{r}-0.0459 \\
(0.2041)\end{array}$ & $\begin{array}{r}-0.0245 \\
(0.4974)\end{array}$ & 1.0000 & & & \\
\hline beta & $\begin{array}{r}-0.0195 \\
(0.5889)\end{array}$ & $\begin{array}{l}0.0820 \\
(0.0230)\end{array}$ & $\begin{array}{r}-0.0793 \\
(0.0280)\end{array}$ & $\begin{array}{l}0.3256 \\
(<.0001)\end{array}$ & 1.0000 & & \\
\hline book-to-market & $\begin{array}{l}0.1297 \\
(0.0003)\end{array}$ & $\begin{array}{r}-0.0553 \\
(0.1253)\end{array}$ & $\begin{array}{r}-0.1774 \\
(<.0001)\end{array}$ & $\begin{array}{r}-0.2751 \\
(<.0001)\end{array}$ & $\begin{array}{r}-0.0552 \\
(0.1262)\end{array}$ & 1.0000 & \\
\hline cash & $\begin{array}{l}0.0291 \\
(0.4210)\end{array}$ & $\begin{array}{r}-0.0102 \\
(0.7773)\end{array}$ & $\begin{array}{l}0.0193 \\
(0.5934)\end{array}$ & $\begin{array}{r}-0.1932 \\
(<.0001)\end{array}$ & $\begin{array}{l}0.1402 \\
(<.0001)\end{array}$ & $\begin{array}{r}-0.0778 \\
(0.0309)\end{array}$ & 1.0000 \\
\hline
\end{tabular}

Numbers in parentheses are $p$-values for the test of the null hypothesis that the correlation coefficient is equal to zero. 
Table A-3. Correlation matrix for Table 5-5, Model 1

\begin{tabular}{|c|c|c|c|c|c|}
\hline & 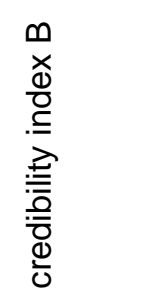 & 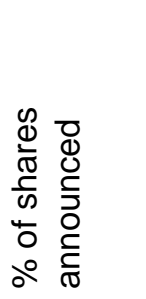 & 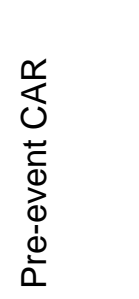 & $\frac{N}{\omega}$ & $\begin{array}{l}\frac{\pi}{ \pm} \\
\Omega\end{array}$ \\
\hline credibility index B & 1.0000 & & & & \\
\hline$\%$ of shares announced & $\begin{array}{l}0.0576 \\
(0.0548)\end{array}$ & 1.0000 & & & \\
\hline pre-event CAR & $\begin{array}{l}0.1957 \\
(<.0001)\end{array}$ & $\begin{array}{l}0.0428 \\
(0.1538)\end{array}$ & 1.0000 & & \\
\hline size & $\begin{array}{r}-0.0770 \\
(0.0102)\end{array}$ & $\begin{array}{r}-0.0509 \\
(0.0900)\end{array}$ & $\begin{array}{r}-0.0325 \\
(0.2785)\end{array}$ & 1.0000 & \\
\hline beta & $\begin{array}{r}-0.0436 \\
(0.1461)\end{array}$ & $\begin{array}{l}0.0434 \\
(0.1477)\end{array}$ & $\begin{array}{r}-0.1020 \\
(0.0007)\end{array}$ & $\begin{array}{l}0.3110 \\
(<.0001)\end{array}$ & 1.0000 \\
\hline
\end{tabular}

Numbers in parentheses are $p$-values for the test of the null hypothesis that the correlation coefficient is equal to zero. 
Table A-4. Correlation matrix for Table 5-5, Model 2

\begin{tabular}{|c|c|c|c|c|c|c|c|}
\hline & 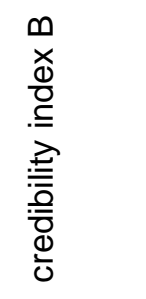 & 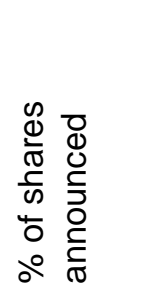 & 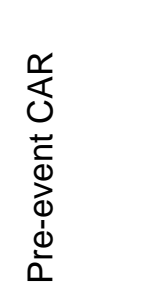 & $\frac{d}{n}$ & $\begin{array}{l}\frac{\pi}{ \pm} \\
0\end{array}$ & 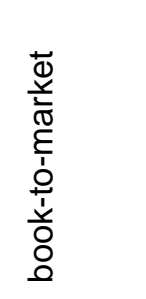 & $\begin{array}{l}\frac{5}{n} \\
\tilde{0} \\
0\end{array}$ \\
\hline credibility index $B$ & 1.0000 & & & & & & \\
\hline$\%$ of shares announced & $\begin{array}{l}0.0464 \\
(0.1989)\end{array}$ & 1.0000 & & & & & \\
\hline pre-event CAR & $\begin{array}{l}0.1917 \\
(<.0001)\end{array}$ & $\begin{array}{l}0.0430 \\
(0.2341)\end{array}$ & 1.0000 & & & & \\
\hline size & $\begin{array}{r}-0.0714 \\
(0.0479)\end{array}$ & $\begin{array}{r}-0.0459 \\
(0.2041)\end{array}$ & $\begin{array}{r}-0.0245 \\
(0.4974)\end{array}$ & 1.0000 & & & \\
\hline beta & $\begin{array}{r}-0.0250 \\
(0.4896)\end{array}$ & $\begin{array}{l}0.0820 \\
(0.0230)\end{array}$ & $\begin{array}{r}-0.0793 \\
(0.0280)\end{array}$ & $\begin{array}{l}0.3256 \\
(<.0001)\end{array}$ & 1.0000 & & \\
\hline book-to-market & $\begin{array}{l}0.0804 \\
(0.0257)\end{array}$ & $\begin{array}{r}-0.0553 \\
(0.1253)\end{array}$ & $\begin{array}{r}-0.1774 \\
(<.0001)\end{array}$ & $\begin{array}{r}-0.2751 \\
(<.0001)\end{array}$ & $\begin{array}{r}-0.0552 \\
(0.1262)\end{array}$ & 1.0000 & \\
\hline cash & $\begin{array}{l}0.0216 \\
(0.5504)\end{array}$ & $\begin{array}{r}-0.0102 \\
(0.7773)\end{array}$ & $\begin{array}{l}0.0193 \\
(0.5934)\end{array}$ & $\begin{array}{r}-0.1932 \\
<.0001\end{array}$ & $\begin{array}{l}0.1402 \\
(<.0001)\end{array}$ & $\begin{array}{r}-0.0778 \\
(0.0309)\end{array}$ & 1.0000 \\
\hline
\end{tabular}

Numbers in parentheses are p-values for the test of the null hypothesis that the correlation coefficient is equal to zero. 


\section{APPENDIX B \\ REUSLTS FROM ALTERNATIVE EVENT STUDY METHODOLOGIES}

\section{Table B-1. Robustness tests using alternative event study methodologies}

\begin{tabular}{lcc|cc|cc|}
\hline Event Study Methodolgy & CAR & $n$ & $t$ & $p$-value & Event Window Estimation Period \\
\hline Event study methodology 1 & $1.79 \%$ & 1507 & 8.56 & $(0.0000)$ & -2 to +2 & -270 to -21 \\
Event study methodology 2 & $1.92 \%$ & 1574 & 9.03 & $(0.0000)$ & -2 to +2 & N/A \\
Event study methodology 3 & $1.87 \%$ & 1450 & 9.06 & $(0.0000)$ & -2 to +2 & -150 to -21 \\
Event study methodology 4 & $1.51 \%$ & 1573 & 9.33 & $(0.0000)$ & -1 to +1 & -270 to -21
\end{tabular}

Event study methodology 1 is the main methodology used in the body of the paper. Abnormal returns are calculated using the market model, with the CFMRC Value Weighted Index used as a proxy for the market return. CAR is calculated over the 5-day window $(-2$ to +2$)$ surrounding the announcement. We use a 250day estimation window (-270 to -21), and exclude any observations that do not have at least 100 days of returns in the estimation window. Observations are excluded that are missing return data in the event window.

Event study methodology 2 calculates abnormal returns by subtracting the CFMRC Value Weighted Index returns from the firms' returns (market adjusted method). CAR is calculated over the 5-day window (-2 to +2 ) surrounding the announcement. Observations are excluded that are missing return data in the event window.

Event study methodology 3 calculates abnormal returns by using the market model, with the CFMRC Value Weighted Index used as a proxy for the market return. CAR is calculated over the 5-day window (-2 to +2$)$ surrounding the announcement. We use a 150 day estimation window (-170 to -21$)$, and exclude any observations that do not have at least 100 days of returns in the estimation window. Observations are excluded that are missing return data in the event window.

Event study methodology 4 calculates abnormal returns by using the market model, with the CFMRC Value Weighted Index used as a proxy for the market return. CAR is calculated over the 3-day window (-1 to +1$)$ surrounding the announcement. We use a 250 day estimation window (-250 to -21$)$, and exclude any observations that do not have at least 100 days of returns in the estimation window. Observations are excluded that are missing return data in the event window. 


\section{APPENDIX C \\ CONSTRUCTION OF ALTERNATIVE CREDIBILITY INDICES}

Credibility Index A2 (previous repurchase dummy)

$$
\text { previous repurchase dummy }_{i, 0}=\left\{\begin{array}{l}
0 \text { if } \frac{\text { shares actually acquired }}{\text { shares }_{i,-1}}=0 \\
1 \text { if } \frac{\text { shares actually } \text { acquired }_{i,-1}}{\text { shares announced }_{i,-1}}>0
\end{array}\right.
$$

Credibility Index A3 (previous repurchase >median dummy)

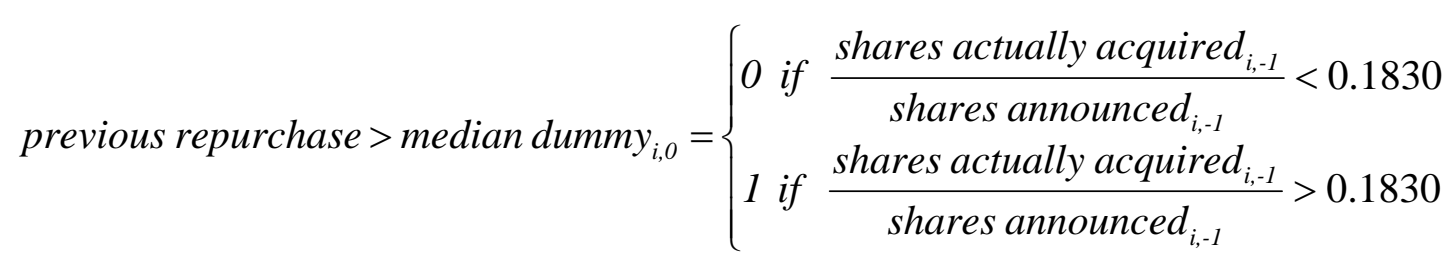

where the median completion rate for the entire sample of share repurchase observations is 18.30 percent. 


\section{Credibility Index B2}

We define a firm as being undervalued $t$ days after the share repurchase announcement if $U_{t}$ is equal to 1 :

$$
U_{t}=\left\{\begin{array}{l}
0 \text { if } P_{t} \succ P_{-3} \\
1 \text { if } P_{t} \leq P_{-3}
\end{array}, \text { or equivalently } U_{t}=\left\{\begin{array}{l}
0 \text { if } \prod_{k=3}^{t}\left(1+R_{i, k}\right) \succ 1.00 \\
1 \text { if } \prod_{k=3}^{t}\left(1+R_{i, k}\right) \leq 1.00
\end{array}\right.\right.
$$

where $P_{t}$ is the firm's stock price $t$ days following the previous repurchase announcement. $P_{-3}$ is the firm's stock price prior to the previous announcement of the share repurchase program. $R_{i, k}$ is the return for firm $i$ on day $k$.

$D_{i, 0}$ measures the opportunity that firm $i$ has to repurchase shares during the repurchasing period for the current (period 0) share repurchase announcement:

$$
D_{i, 0}=\frac{\sum_{t=3}^{250} U_{t}}{248}
$$

Therefore, credibility index B2 is then constructed in the familiar method as follows:

$$
\begin{aligned}
{\text { credibility index } B 2_{i, 0}} & =\frac{\text { shares actually acquired }_{i,-1}}{\text { shares announced }}-D_{i,-1} \\
& =\text { credibility index } A_{i,-1}-D_{i,-1}
\end{aligned}
$$




\section{Credibility Index B3}

We define a firm as being undervalued over the repurchasing period if $U$ is equal to 1 :

$$
U=\left\{\begin{array}{l}
0 \text { if Average } P \succ P_{-3} \\
1 \text { if Average } P \leq P_{-3}
\end{array}\right.
$$

where Average $P$ is the firm's average stock price over relative days +3 to +250 .

$D_{i, 0}$ measures the opportunity that firm $i$ has to repurchase shares during the repurchasing period for the current (period 0) share repurchase announcement and is either equal to 1 or 0:

$$
D_{i, 0}=U
$$

Therefore, credibility index B3 is then constructed in the familiar method as follows:

$$
\begin{aligned}
{\text { credibility index } B 3_{i, 0}} & =\frac{\text { shares actually acquired }_{i,-1}}{\text { shares announced }}-D_{i,-1} \\
& =\text { credibility index } A_{i,-1}-D_{i,-1}
\end{aligned}
$$




\section{Credibility Index B4}

We define a firm as being undervalued $t$ days after the share repurchase announcement if $U_{t}$ is equal to 1 :

$$
U_{t}=\left\{\begin{array}{l}
0 \text { if } P_{t} \succ P_{-3} \times \prod_{k=3}^{t}\left(1+\hat{\alpha}+\hat{\beta} R_{M, k}\right) \\
1 \text { if } P_{t} \prec P_{-3} \times \prod_{k=3}^{t}\left(1+\hat{\alpha}+\hat{\beta} R_{M, k}\right)
\end{array} \text { for } 3 \leq t \leq 250\right.
$$

where $P_{t}$ is the firm's stock price $t$ days following the previous repurchase announcement. $P_{-3}$ is the firm's stock price prior to the previous announcement of the share repurchase program. $R_{M, k}$ is the return in the CFMRC Value Weighted Index.

$D_{i, 0}$ measures the opportunity that firm $i$ has to repurchase shares during the repurchasing period for the current (period 0) share repurchase announcement:

$$
D_{i, 0}=\frac{\sum_{t=3}^{250} U_{t}}{248}
$$

Therefore, credibility index B4 is then constructed as follows:

$$
\begin{aligned}
{\text { credibility index } B 4_{i, 0}}^{=} & 1-\left[\left(1-\frac{\text { shares actually acquired }_{i,-1}}{\text { shares announced }}\right) \times D_{i,-1}\right. \\
& =1-\left[\left(1-\text { credibility index } A_{i,-1}\right) \times D_{i,-1}\right]
\end{aligned}
$$

Credibility index B4 takes a value between 0 and 1 . In addition, the theoretical interpretation of credibility index B4 is different from the other variations of credibility index B. Let us define announcement credibility as a measure of share repurchase performance, conditional on the firm having the opportunity to perform (i.e. opportunity to repurchase arises when firm is undervalued). Then, (1-credibility index $A$ ) can be viewed as measuring the lack of share repurchase performance. We then multiply this measurement by the firm's opportunity to perform $\left(D_{i, 0}\right)$. Think of $D_{i, 0}$ as a multiplier that magnifies the lack of performance measurement for those firms that had a greater opportunity to perform. Lastly, we subtract this result from 1 to arrive at a share repurchase performance score which can be interpreted as a credibility index.

In other words, all repurchasing firms start out with full credibility after the announcement of the share repurchase program. The firm will lose credibility only if it fails to complete its share repurchase program. For firms that fail to fulfill their repurchase programs, those firms that had the opportunity to repurchase (i.e. values of $\mathrm{D}_{\mathrm{i}, 0}$ that are close to 1 ) but failed to do so will be lose more credibility compared to firms that did not have the opportunity to repurchase shares (i.e. values of $\mathrm{D}_{\mathrm{i}, 0}$ that are close to $0)$. 
Table C-1. Multivariate regression results for previous completion dummy and previous completion >median dummy

\begin{tabular}{|c|c|c|c|c|}
\hline Model & 1 & 2 & 3 & 4 \\
\hline Intercept & $\begin{array}{l}0.0287 \text { ** } \\
(0.0001)\end{array}$ & $\begin{array}{l}0.0220 \text { ** } \\
(0.0227)\end{array}$ & $\begin{array}{l}0.0264 \text { ** } \\
(0.0000)\end{array}$ & $\begin{array}{l}0.0174 \text { * } \\
(0.0449)\end{array}$ \\
\hline \multicolumn{5}{|l|}{ CONTROL Variables: } \\
\hline$\%$ of shares announced & $\begin{array}{l}0.0112 \\
(0.8589)\end{array}$ & $\begin{array}{l}0.0338 \\
(0.6423)\end{array}$ & $\begin{array}{l}0.0091 \\
(0.8847)\end{array}$ & $\begin{array}{l}0.0310 \\
(0.6694)\end{array}$ \\
\hline pre-event CAR & $\begin{array}{l}-0.0151 \text { ** } \\
(0.0014)\end{array}$ & $\begin{array}{l}-0.0137 \\
(0.0145)\end{array}$ & $\begin{array}{l}-0.0151 \text { ** } \\
(0.0013)\end{array}$ & $\begin{array}{l}-0.0137 \\
(0.0144)\end{array}$ \\
\hline size & $\begin{array}{c}-3.00 \mathrm{E}-05 \text { ** } \\
(0.0000)\end{array}$ & $\begin{array}{c}-2.58 \mathrm{E}-05^{* *} \\
(0.0001)\end{array}$ & $\begin{array}{c}-2.98 \mathrm{E}-05^{* *} \\
(0.0000)\end{array}$ & $\begin{array}{c}-2.61 \mathrm{E}-05^{* *} \\
(0.0000)\end{array}$ \\
\hline beta & $\begin{array}{l}0.0109 \text { ** } \\
(0.0153)\end{array}$ & $\begin{array}{l}0.0085 \\
(0.1048)\end{array}$ & $\begin{array}{l}0.0109 \text { ** } \\
(0.0149)\end{array}$ & $\begin{array}{l}0.0088 \text { * } \\
(0.0946)\end{array}$ \\
\hline book-to-market & & $\begin{array}{l}0.0032 \text { * } \\
(0.0953)\end{array}$ & & $\begin{array}{l}0.0029 \\
(0.1316)\end{array}$ \\
\hline cash & & $\begin{array}{l}0.0462 \text { ** } \\
(0.0033)\end{array}$ & & $\begin{array}{l}0.0455 \text { ** } \\
(0.0038)\end{array}$ \\
\hline \multicolumn{5}{|l|}{ CREDIBILITY Variables: } \\
\hline previous completion rate dummy & $\begin{array}{l}0.0040 \\
(0.4672)\end{array}$ & $\begin{array}{r}-0.0015 \\
(0.8085)\end{array}$ & & \\
\hline previous completion rate $>$ median dummy & & & $\begin{array}{l}0.0102 \text { ** } \\
(0.0122)\end{array}$ & $\begin{array}{l}0.0072 \\
(0.1202)\end{array}$ \\
\hline $\bar{n}$ & 1112 & 769 & 1112 & 769 \\
\hline adjusted $\mathrm{R}^{2}$ & 0.0373 & 0.0549 & 0.0423 & 0.0578 \\
\hline F-test & 9.6018 ** & 7.3741 ** & 10.8053 ** & 7.7342 ** \\
\hline
\end{tabular}

Table C-1 reports cross-sectional regression results of the initial market reaction to the share repurchase announcement. The dependent variable is the cumulative abnormal return calculated using the market model for the 5-day event window $(-2,+2)$ surrounding the announcement date. The explanatory variables are as follows: \% of share announced is the percent of total shares outstanding that the repurchaser announces it is repurchasing, pre-event $C A R$ is the prior one-year cumulative abnormal return over the oneyear window (-3 to -252), size is the rank of the firm's market capitalization in the sample, beta is the measure of systematic risk measured by the market model coefficient estimated over the estimation window (-270 to -21), book-to-market is the firm's ratio of book to market equity in the sample, cash is the amount of cash and short term investments scaled by total assets, previous repurchase dummy is a dummy variable that takes the value of 1 if the firm's most recent share repurchase completion rate (calculated as the number of shares actually acquired divided by the target number of shares) is greater than $0 \%$, and previous repurchase >median dummy is a dummy variable that takes the value of 1 if the firm's most recent share repurchase completion rate is greater than the sample median completion rate $(18.3 \%)$ and 0 otherwise. ** and $*$ denote significance at the 1 percent and 5 percent levels, respectively. We also include the test statistic for the F-test that tests the null hypothesis that all parameter estimates are simultaneously equal to zero. 
Table C-2. Multivariate regression results for credibility index B2, B3, and B4

\begin{tabular}{|c|c|c|c|c|c|c|}
\hline Model & 1 & 2 & 3 & 4 & 5 & 6 \\
\hline Intercept & $\begin{array}{l}0.0336 \text { ** } \\
(0.0000)\end{array}$ & $\begin{array}{l}0.0232 \text { ** } \\
(0.0064)\end{array}$ & $\begin{array}{l}0.0326 \text { ** } \\
(0.0000)\end{array}$ & $\begin{array}{l}0.0220 \text { ** } \\
(0.0086)\end{array}$ & $\begin{array}{l}0.0215 \text { ** } \\
(0.0033)\end{array}$ & $\begin{array}{l}0.0082 \\
(0.3927)\end{array}$ \\
\hline \multicolumn{7}{|l|}{ CONTROL Variables: } \\
\hline$\%$ of shares announced & $\begin{array}{l}0.0071 \\
(0.9108)\end{array}$ & $\begin{array}{l}0.0263 \\
(0.7169)\end{array}$ & $\begin{array}{l}0.0083 \\
(0.8950)\end{array}$ & $\begin{array}{l}0.0259 \\
(0.7209)\end{array}$ & $\begin{array}{l}0.0112 \\
(0.8584)\end{array}$ & $\begin{array}{l}0.0307 \\
(0.6711)\end{array}$ \\
\hline pre-event CAR & $\begin{array}{l}-0.0173 \text { ** } \\
(0.0005)\end{array}$ & $\begin{array}{l}-0.0163 \text { ** } \\
(0.0049)\end{array}$ & $\begin{array}{l}-0.0176 \text { ** } \\
(0.0003)\end{array}$ & $\begin{array}{l}-0.0173 \text { ** } \\
(0.0027)\end{array}$ & $\begin{array}{l}-0.0170 \text { ** } \\
(0.0004)\end{array}$ & $\begin{array}{l}-0.0166 \text { ** } \\
(0.0035)\end{array}$ \\
\hline size & $\begin{array}{c}-3.14 \mathrm{E}-05 \text { * } \\
(0.0000)\end{array}$ & $\begin{array}{c}-2.77 \mathrm{E}-05 \text { ** } \\
(0.0000)\end{array}$ & $\begin{array}{c}-3.07 \mathrm{E}-05 \text { * } \\
(0.0000)\end{array}$ & $\begin{array}{c}-2.71 \mathrm{E}-05 \text { * } \\
(0.0000)\end{array}$ & $\begin{array}{c}-2.93 E-05 \text { ** } \\
(0.0000)\end{array}$ & $\begin{array}{c}-2.53 \mathrm{E}-05^{* *} \\
(0.0001)\end{array}$ \\
\hline beta & $\begin{array}{l}0.0112 \text { ** } \\
(0.0125)\end{array}$ & $\begin{array}{l}0.0091 \text { * } \\
(0.0849)\end{array}$ & $\begin{array}{l}0.0111 \text { ** } \\
(0.0132)\end{array}$ & $\begin{array}{l}0.0092 * \\
(0.0799)\end{array}$ & $\begin{array}{l}0.0107 \text { ** } \\
(0.0164)\end{array}$ & $\begin{array}{l}0.0086 \\
(0.1026)\end{array}$ \\
\hline book-to-market & & $\begin{array}{l}0.0030 \\
(0.1231)\end{array}$ & & $\begin{array}{l}0.0031 \\
(0.1050)\end{array}$ & & $\begin{array}{l}0.0027 \\
(0.1586)\end{array}$ \\
\hline cash & & $\begin{array}{l}0.0456 \text { ** } \\
(0.0036)\end{array}$ & & $\begin{array}{l}0.0461 \text { ** } \\
(0.0032)\end{array}$ & & $\begin{array}{l}0.0461 \text { ** } \\
(0.0032)\end{array}$ \\
\hline \multicolumn{7}{|l|}{ CREDIBILITY Variables: } \\
\hline credibility index B2 & $\begin{array}{l}0.0074 \text { * } \\
(0.0940)\end{array}$ & $\begin{array}{l}0.0082 \text { * } \\
(0.0996)\end{array}$ & & & & \\
\hline credibility index B3 & & & $\begin{array}{l}0.0082 \text { ** } \\
(0.0285)\end{array}$ & $\begin{array}{l}0.0102 \text { ** } \\
(0.0146)\end{array}$ & & \\
\hline credibility index B4 & & & & & $\begin{array}{l}0.0146 \text { ** } \\
(0.0204)\end{array}$ & $\begin{array}{l}0.0186 \text { ** } \\
(0.0090)\end{array}$ \\
\hline $\mathrm{n}$ & 1112 & 769 & 1112 & 769 & 1112 & 769 \\
\hline adjusted $\mathrm{R}^{2}$ & 0.0392 & 0.0582 & 0.0410 & 0.0622 & 0.0415 & 0.0633 \\
\hline F-test & 10.0775 ** & $7.7799 * *$ & 10.4948 ** & $8.2790 * *$ & 10.6166 ** & 8.4112 ** \\
\hline
\end{tabular}

Table C-2 reports cross-sectional regression results of the initial market reaction to the share repurchase announcement. The dependent variable is the cumulative abnormal return calculated using the market model for the 5-day event window $(-2,+2)$ surrounding the announcement date. The explanatory variables are as follows: \% of share announced is the percent of total shares outstanding that the repurchaser announces it is repurchasing, pre-event CAR is cumulative abnormal return (calculated as the firm return minus the return on the CFMRC value weighted index) over the one-year period prior to the event window (-3 to -252), size is the rank of the firm's market capitalization, beta is the measure of systematic risk measured by the market model coefficient estimated over the estimation window (-270 to -21), book-tomarket is the firm's ratio of book to market equity, cash is the amount of cash and short term investments scaled by total assets, and credibility index B2, B3, and B4 are calculated according to Appendix C. The numbers in parentheses are $p$-values. ${ }^{* *}$ and $*$ denote significance at the 1 percent and 5 percent levels, respectively. A $p$-value of $(0.000)$ denotes that the $p$-value is less than 0.001 . We also include the test statistic for the F-test that tests the null hypothesis that all parameter estimates are simultaneously equal to zero. 


\section{APPENDIX D \\ TSX E-REVIEW SHARE REPURCHASE SUMMARY}

An excerpt of the summary for normal course issuer bids from the June, 2005 edition of the TSX E-Review is provided on the next page. ${ }^{58}$

\footnotetext{
58 The one page excerpt is the property of the TSX and no part of this excerpt may be reproduced in any form without prior permission from the Toronto Stock Exchange. See page 100 for a copy of the written correspondence from the TSX authorizing the inclusion of the material in Figure D-1.
} 
Figure D-1. Example of TSX share repurchase summary

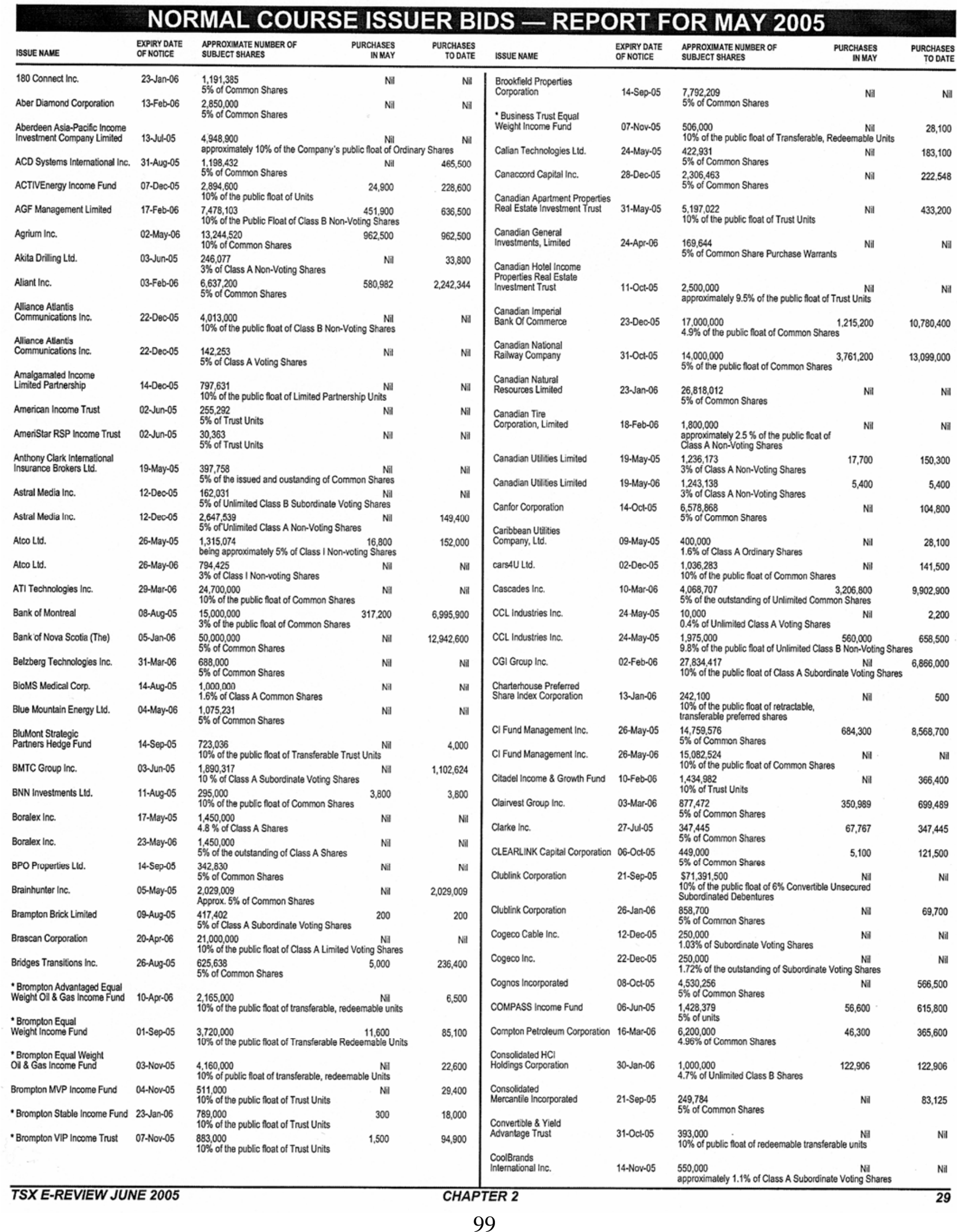


Figure D.2. Copy of the written correspondence from the TSX authorizing the inclusion of the material in Figure D-1

Date: Thu, 05 Oct 2006 07:08:36 -0400

From: Catherine.McGravey@tsxdatalinx.com

To: $\quad$ "Luke J. Schmidt" <ljs615@mail.usask.ca>

Subject: Re: Permission to reproduce TSX E-Review

Please accept this note as permission to use page 29 of the June 2005 TSX

Review in your dissertation.

Catherine McGravey

Production Manager

Editor TSX Review

Datalinx

416-947-4655

Catherine.McGravey@tsxdatalinx.com 